\title{
An ill wind? Terrorist attacks and CEO compensation
}

\author{
YUNHAO DAI \\ Huazhong University of Science and Technology \\ P. RAGHAVENDRA RAU \\ University of Cambridge \\ ARIS STOURAITIS \\ Hong Kong Baptist University \\ WEIQIANG TAN \\ Hong Kong Baptist University
}

October 2018

Journal of Financial Economics, forthcoming

\begin{abstract}
Using multiple measures of attack proximity, we show that CEOs employed at firms located near terrorist attacks earn an average pay increase of $12 \%$ after the attack relative to CEOs at firms located far from attacks. CEOs at terrorist attack-proximate firms prefer cash-based compensation increases (e.g., salary and bonus) over equity-based compensation (e.g., options and stocks granted). The effect is causal and it is larger when the bargaining power of the CEO is high. Other executives and workers do not receive a terrorist attack premium.
\end{abstract}

Keywords: Terrorist attacks, Executive compensation, Compensation structure, CEO labor market, Non-monetary compensation

JEL classification: G15; G30; G34

Dai: School of Economics, Huazhong University of Science and Technology, Wuhan, China (email: daiyunhao@hust.edu.cn). Rau: Cambridge Judge Business School, Trumpington Street, Cambridge CB2 1AG, United Kingdom (email: r.rau@jbs.cam.ac.uk). Stouraitis, Tan: School of Business, Hong Kong Baptist University, Renfrew Road, Kowloon Tong, Hong Kong, People's Republic of China (stoura@hkbu.edu.hk; wqtan@hkbu.edu.hk). We thank an anonymous referee, Kee-Hong Bae, Claudia Custodio, Mustafa Leeq, Christoph Loch, Ernst Maug, Sucheta Nadkarni, participants at the Asian Finance Association 2018 Annual Meeting in Tokyo, and the International Finance Symposium 2018 in Kissamos for comments on earlier drafts. Dai is grateful for financial support from the National Natural Science Foundation of China (Grant No. 71702061). Tan is grateful for research support from Faculty Research Grant of Hong Kong Baptist University. 


\section{Introduction}

The threat of terrorist attacks has intensified in recent years. According to the Global Terrorism Database (GTD) constructed by the National Consortium for the Study of Terrorism and Response to Terrorism (START), more than 2,600 terrorist attacks were conducted in the United States (U.S.) between 1970 and 2014 (Miller, 2016). The growing threat of terrorism has alarmed executives. The $19^{\text {th }}$ Annual Global CEO Survey conducted by PricewaterhouseCoopers emphasizes that "geopolitical uncertainty (exacerbated by regional conflicts and increased terrorism attacks) is a top concern for nearly three quarters of CEOs" (PwC, 2016, p.2).

While there is a burgeoning literature on the impact of terrorist attacks on the economy and the stock market ${ }^{1}$, there is little micro-level evidence on specifically how firms and executives react to terrorist attacks. In this paper, we investigate whether chief executive officers (CEOs) renegotiate the level or structure of their compensation as a specific response to terrorist attacks.

This is an important topic. Though CEO compensation has been extensively investigated over the past three decades, there are only a relative handful of papers that investigate how nonmonetary factors affect executive compensation and the evidence in these papers is mixed (Rau, 2015). Deng and Gao (2013) find that companies located in locations with a low quality of life (based on factors such as crime rates or cost of living) pay higher compensation to their CEOs than firms located in more livable locations. Focke, Maug, and Niessen-Ruenzi (2017) show that CEOs of prestigious firms (based on Fortune's list of Most Admired Companies, MAC) earn less, and suggest the CEOs are willing to trade off monetary compensation in return for additional status and career benefits from working for a publicly admired corporation. However, using exactly the

\footnotetext{
${ }^{1}$ For example, terrorist attacks have been shown to adversely affect macroeconomic conditions and the performance of financial markets, with impacts on economic growth, foreign direct investment, property prices, consumer and investor confidence, the cost of capital, and stock prices.
} 
same database, Cheng, Liu, McConnell, and Rosenblum (2017) show that CEOs of firms that increase their rankings on the MAC list, earn increases in compensation. Similarly, Francis, Hasan, John, and Waisman (2016) find that CEOs in metropolitan areas (which have a wealth of consumption amenities and employment opportunities and are generally more livable) are paid more than CEOs in rural areas. While these studies all attempt to solve the causality and endogeneity issues in varying ways, at the end, non-monetary factors such as prestige, livability, etc., are sufficiently difficult to define econometrically ${ }^{2}$, that it is problematic to cleanly attribute causality to the relation between non-monetary factors and compensation.

In contrast, in our paper, we examine the causal effect of a specific non-monetary factor, a terrorist attack, on compensation. A terrorist attack is a clean, sharp, and specific event that forms an unexpected unambiguous deterioration in the quality of the CEO's living environment. Hence if CEOs do indeed react to non-monetary factors in total compensation, we should see an increase in their pay following terrorist attacks.

There are two plausible reasons to believe that CEOs might seek an increase in their level of compensation following terrorist attacks, one rational and one behavioral. The rational explanation is based on the literature that depicts top managers as risk averse. Harris and Raviv (1979) argue that executives prefer to structure their compensation to allow them to bear minimal personal risks. Peters and Wagner (2014) show that the probability of a CEO being fired is higher when the firm is experiencing volatile industry conditions. In turn, compensation is higher when turnover risk increases. Terrorism risk forms an example of a low-probability event with extreme negative consequences, a situation dramatically different from industry volatility. However, by posing

\footnotetext{
${ }^{2}$ For example, Yonker (2016) shows that CEOs have strong local geographic preferences. Compensation is lower for local CEOs who earn utility from living locally. While Yonker's results are consistent with those of Deng and Gao (2013), the mechanism is very different across the two papers.
} 
severe personal safety threats to managers, terrorist attacks also increase the risks and uncertainty that executives face. The behavioral explanation is based on the literature that has shown that negative events, such as terrorist attacks, adversely affect emotions. Metcalfe, Powdthavee, and Dolan (2011) show that the September 11, 2001 attack in the U.S. resulted in reduced levels of subjective well-being. Ahern (2012) demonstrates that terrorist attacks have psychological impacts on trust and perceptions of well-being. Antoniou, Kumar, and Maligkris (2016a) show that analysts located near locations that have experienced terrorist attacks are more likely to issue pessimistic forecasts than those located far from such locations. Faced with increased psychological stress, CEOs may demand larger compensation packages in order to compensate them for their perceived loss of well-being.

There are also plausible reasons to believe that terrorist attacks will affect the structure of compensation. As noted above, prior studies have shown that terrorist attacks can adversely affect macroeconomic conditions and the performance of financial markets. ${ }^{3}$ The consequent potential reduction in stock returns and the associated values of stock options may lead executives to reduce their preference for long-term incentive contracts (involving stock grants or stock options), instead displaying a preference for cash awards. In addition, if the adverse effects on firms increase the likelihood of financial distress (Guan, $\mathrm{Li}$ and $\mathrm{Xu}, 2016$ ), the increased uncertainty caused by terrorist attacks may cause executives to adopt conservative corporate policies to avoid the risk of potential shocks (Antoniou, Kumar and Maligkris, 2016b). Finally, this uncertainty with respect to future firm performance may also impact the value of a manager's human capital, which is correlated with the firm's stock performance when a large part of executive compensation is

\footnotetext{
3 Examples include Abadie and Gardeazabal (2003; 2008), Blomberg, Hess, and Orphanides (2004), Bandyopadhyay, Sandler, and Younas (2014), Chesney, Reshetar, and Karaman (2011), Karolyi and Martell (2010), Michel-Kerjan and Pedell (2006), Eckstein and Tsiddon (2004), Procasky and Ujah (2016), Di Tella and Schargrodsky (2004), Gould and Stecklov (2009), Arin, Ciferri, and Spagnolo (2008), Brounen and Derwall (2010), Chen and Siems (2004), Kollias, Papadamou, and Stagiannis (2011), or Nikkinen and Vähämaa (2010).
} 
granted in the form of stock. For all these reasons, subsequent to the attack, affected CEOs may prefer to be granted a larger share of their compensation in the form of cash payments than stock or option payments.

In this study, we examine a sample of terrorist attacks that occurred in the U.S. from 1992 to 2013, distinguishing firms that are located near terrorist attacks from those that are not. We identify whether a firm is affected by a terrorist attack by calculating the distance between the headquarters of the firm and the terrorist attack location (a measure of attack proximity). In our main tests, we use a difference-in-difference specification where our attack proximity indicator variable is timevarying - it takes the value one for firms that are proximate to an attack only in the period after the attack. It takes the value zero for the treatment firms before the attack and for all the remaining firms. We find a statistically and economically significant positive relation between terrorist attacks and CEO pay. On average, CEOs working at firms in areas that are subject to a terrorist attack earn a terrorist pay premium of $12 \%$ following the attack. This result holds after controlling for time and firm fixed effects. The structure of compensation also changes. CEOs of companies located near terrorist attacks subsequently receive higher levels of cash compensation (salary and bonus) than CEOs of firms located in safer locations. Effectively, the entire post-attack increase in $\mathrm{CEO}$ compensation is the result of increases in cash compensation, while the increase in equitybased (including option) compensation is insignificant.

There are no changes in the financial or operational policies of the firm, suggesting that the adoption of conservative financial policies and their subsequent impact on option values is not likely to explain why CEOs prefer increases in cash compensation to option compensation. However, firms affected by terrorist attacks earn poorer returns than their matched peers in the 
year after the attack, suggesting that the reduction in equity-based compensation value may partially account for a rational preference for cash-based compensation increases.

Our results are robust to examining individual annual effects in the years both before and after the attack in the spirit of Bertrand and Mullainathan (2003) and to using a propensity score matching (PSM) method to match firms located near terrorist attack scenes with firms with similar characteristics located farther away from such scenes within the same state.

It is not obvious however, that all CEOs will obtain equally high pay levels in response to negative shocks to non-monetary factors. While it is plausible to expect CEOs to demand higher pay levels, the probability that firms will supply higher compensation levels depends on the bargaining power of the $\mathrm{CEO}$. We further find that the terrorist-proximity premium is larger for more powerful CEOs, where CEO power is defined using standard measures of corporate governance. We find no such premium for other executives and rank-and-file employees.

Our study contributes to two streams of literature. First, it contributes to the executive compensation literature. There is very limited research on non-monetary factors that influence executive compensation. Our findings enhance our understanding of how specific non-monetary factors affect CEO compensation. Our paper also contributes to the literature on how risk affects CEO compensation. Terrorism risk forms an example of a low-probability event with extreme negative consequences, a situation dramatically different from industry volatility studied in prior papers, and we show that it has similar effects on compensation. Second, our study contributes to the extensive literature that analyzes the implications of terrorism. Early prior studies focus on the macroeconomic effects of terrorism. ${ }^{4}$ Only recently have studies shifted their focus to

\footnotetext{
4 See, for example, Abadie and Gardeazabal (2003), Blomberg, Hess, and Orphanides (2004), or Bandyopadhyay, Sandler, and Younas (2014).
} 
microeconomic effects. Our study extends this latter line of literature by showing that terrorist attacks have economically significant impacts on CEO compensation.

\section{Sample Selection and Methodology}

\subsection{Data and sample selection}

The data for this study are obtained from multiple sources. We obtain data on terrorist attacks from the Global Terrorism Database GTD (http:/www.start.umd.edu/gtd/), an open-source database compiled by the National Consortium for the Study of Terrorism and Responses to Terrorism (START), and located at the University of Maryland, that contains systematic data on domestic and international terrorist events around the world (START, 2016). ${ }^{5}$ From this database, we collect information on the date and location of each terrorist attack that occurred in the U.S. between 1992 and 2013. Appendix A provides a classification of the 569 terrorist attacks recorded in the U.S. during our sample period. The most frequent attacks occurred in 1995, when the number of attacks reached 62, decreasing to a relatively low level after 2006. The attack targets are usually businesses, private citizens, and property. Figure 1 shows the frequency of attacks by state. Overall, though terrorist attacks appear to occur in a large number of states, there is considerable variation between the states. California, in particular, was attacked most frequently (97 times).

We obtain executive compensation data from the ExecuComp database. The dataset provides detailed information on salaries, bonuses, options and stock awards, and other compensation items. We obtain financial information from Compustat and stock price information from the Center for Research in Security Prices (CRSP).

\footnotetext{
5 According to the definition used by START, for inclusion in the database, "each incident... had to be an intentional act of violence or threat of violence by a non-state actor. In addition, two of the following three criteria also had to be met: 1 . The violent act was aimed at attaining a political, economic, religious, or social goal; 2 . The violent act included evidence of an intention to coerce, intimidate, or convey some other message to a larger audience (or audiences) other than the immediate victims; and 3 . The violent act was outside the precepts of International Humanitarian Law."
} 
Our final sample consists of 2,087 U.S. publicly listed firms for which we can identify the location of their headquarters and who have data in Compustat and CRSP (representing 22,561 firm-year observations).

\subsection{Regression models}

Following Bertrand and Mullainathan (2003), in our main tests, we use a difference-indifference model (DiD) to capture the impact of terrorist attacks on the level and composition of CEO compensation. We classify a firm as treated if the attack occurs within 100 miles of the firm's headquarters and no other attack occurred within 100 miles of the same firm over the prior three years. To compute the distance to the attack, we manually collect latitude and longitudinal information on the location of the firm's headquarters for all publicly listed firms. Then we calculate the distance between the coordinates of the firm's headquarters and the locations of terrorist attacks following the procedure in Vincenty (1975). The control group includes the treatment firms before the attack and all remaining firms. We use the following empirical model:

$\ln \left(\right.$ CEO Pay Variable $_{i t+1}=\alpha+\beta_{1}$ Attack Proximity $_{i t}+\beta_{2}$ Firm size $_{i t}+\beta_{3}$ Volatility $_{i t}+$ $\beta_{4} R E T_{[-12,0] i t}+\beta_{5} R O A_{i t}+\beta_{6} M / B$ Ratio ${ }_{i t}+\beta_{7}$ Cash/Assetsit $+\beta_{8 \text { Leverageit }+\beta_{9} \text { Capex } / \text { Assetsit }}+$ $\beta_{10}$ CEO Age $e_{i t}+\beta_{11}$ CEO Ownership $i t+\alpha_{i}+\delta_{t}+\varepsilon_{i t+1}$

where $i$ indexes firms, $t$ indexes year, the $\alpha_{i}$ s are firm fixed effects and the $\delta_{t}$ s are year fixed effects.

In measuring the effect on the level of overall CEO compensation, our dependent variable, $\ln (\text { CEO Pay Variable })_{i t+1}$, is the natural logarithm of CEO Total Pay for firm $i$ in year $t+1$. Total Pay is the variable TDCl in ExecuComp, consisting of salary, bonuses, value of restricted stocks granted, value of options granted (following Black and Scholes, 1973), long-term incentive payouts, and other types of compensation. TDCl estimates the value of total compensation awarded (but not necessarily realized) to the executive that year. For robustness, we repeat our 
analysis using an alternative pay measure, the Ex Post Pay. Ex Post Pay is the item TDC2 in ExecuComp. As described in Kaplan and Rauh (2010), TDC2 estimates the value of total compensation realized by the executive in a given year. This is the sum of salary, bonus, the value of restricted stock granted, the net value of stock options exercised, and the value of long-term incentive payouts. It is similar to $T D C 1$ except that it replaces the value of options granted with the value of options exercised during the year.

To analyze the effect on the structure of CEO compensation, we use two sets of variables. In an analysis of the levels of the CEO compensation components, the dependent variables are the natural logarithm of a CEO's Salary, Bonus, value of restricted stock granted (Stock Value), value of options granted (Option Value), and long-term incentive payouts (LTIP Value). We further categorize the different components of compensation into two types: (1) cash compensation (natural logarithm of the sum of Salary and Bonus) and (2) equity-based compensation (natural logarithm of the sum of Stock Value, Option Value, and LTIP Value). We use the Cash to Total Compensation Ratio, defined as the proportion of cash compensation (sum of salary and bonus) in the total compensation, as a final dependent variable.

Our primary analysis variable is Attack Proximity, a time-variant indicator variable that takes the value one for firms that are proximate to an attack only in the period after the attack. It takes the value zero for the treatment firms before the attack and for all the remaining firms. In robustness tests, we use alternative distances as cutoffs to define attack proximity (e. g., 30 miles, 50 miles, or 200 miles as cutoffs, respectively), or we use only the first attack that is within 100 miles of a firm as a treatment, but obtain similar results.

Following the existing compensation literature (e.g., Core, Holthausen, and Larcker, 1999; Deng and Gao, 2013), we control for a series of firm-specific characteristics in our model. Firm 
Size is measured by the natural logarithm of firm sales and is expected to be positively related to compensation (Gabaix and Landier, 2008; Tervio, 2008). Volatility is the standard deviation of monthly stock returns over the past 60 months and is expected to be positively related to compensation (Cyert, Kang, Kumar, and Shah, 1997). $R E T_{[-12,0]}$ is the buy-and-hold return of a firm's stock over the past 12 months. $R O A$ refers to net income before extraordinary items and discontinued operations divided by total assets. M/B Ratio is measured as the market value of equity divided by the book value of equity, in which the market value is obtained as the fiscal year closing price multiplied by the number of common shares outstanding. We expect $R E T_{[-12,0]}, R O A$, and $M / B$ Ratio to be positively related to compensation if CEO compensation is correlated with firm performance (Conyon, 2014). Cash/Assets is the ratio of cash items to total assets. Leverage is the sum of current liabilities and long-term debt divided by total assets. Capex/Assets is the ratio of capital expenditures to total assets.

The CEO-specific characteristics included in the specifications are CEO Age and CEO Ownership. Previous studies have used the CEO's age as a proxy to measure the CEO horizon problem which can affect his or her preferences on compensation structure (e.g., Gibbons and Murphy, 1992; Yim, 2013). CEO Ownership is the proportion of shares held by the CEO, excluding options, in shares outstanding. Given that the existing literature (e.g., Core, Holthausen, and Larcker, 1999) finds a substitution effect between CEO stock ownership and annual compensation, we expect $C E O$ Ownership to be negatively associated with CEO compensation.

We also control for fixed differences between the control and treatment groups via firm and year fixed effects. Firm fixed effects control for all time invariant variables that might affect compensation (such as industry, location, or agency concerns), whereas time fixed effects control for time variation in compensation common to all firms in the sample. The standard errors are 
clustered by firm and year (Bertrand, Duflo, and Mullainathan, 2004). All monetary variables are measured in 2014 constant dollars. Detailed definitions of all variables used in this study are summarized in Appendix B.

\section{Empirical results}

\subsection{Descriptive statistics}

Table 1 presents descriptive statistics of the variables used in the analysis across three different groups: (1) the treatment firms in the years prior to the attacks; (2) the treatment firms in the years after the attacks; and (3) control firms that are not located near any attacks. Approximately $15.5 \%$ of firm-year observations are affected by terrorist attacks. The mean (median) CEO total pay is $\$ 5.9(\$ 3.9)$ million for treatment firms prior to the attack, in contrast to $\$ 7.3$ (\$5.1) million for treatment firms after the attack, and \$5.3 (\$3.3) million for control firms. The mean (median) cash-based pay is $\$ 1.6(\$ 1.1)$ million for treatment firms prior to the attack, \$2.0 (\$1.3) million for treatment firms after the attack, and \$1.5 (\$1.0) million for control firms. Similarly, the mean (median) level of equity-based pay is $\$ 3.2$ (\$1.1) million for treatment firms prior the attack, $\$ 4.0(\$ 1.8)$ million for treatment firms after the attack, and $\$ 2.9(\$ 1.0)$ million for control firms.

Comparing the characteristics of the treated to the control firms, the control firms appear to be significantly different from the treatment firms prior to the attack across most firm characteristics, and the difference widens dramatically after the attack. Treated firms are significantly larger, earn higher operating returns, trade at higher market-to-book ratios, and have significantly lower volatility, cash levels, leverage and levels of capital expenditure. This is not entirely surprising. Terrorists are not likely to attack locations at random. They are probably likelier to attack larger and richer population centers. Firms located in these areas are more likely 
to differ along firm characteristics from firms in non-attacked areas. To control for the effect of these omitted variables, we also use a PSM methodology where we include firm fixed effects to control for all time-invariant variables that might affect compensation, such as industry, location, or agency concerns, time fixed effects to control for time variation in compensation common to all firms in the sample, and time-varying firm traits such as size and leverage. To mitigate the effect of outliers in our subsequent tests, we also winsorize all firm-year continuous variables at the $1 \%$ and $99 \%$ levels, respectively.

\subsection{Effect of terrorist attacks on executive compensation levels}

Table 2 presents the baseline difference-in-difference regression results of the effect of terrorist attacks on total CEO pay. In each case, we control for firm and year fixed effects. Model (1) includes Attack Proximity as the only independent variable. The estimated coefficient on Attack Proximity is 0.099 and is significant at the $1 \%$ level, indicating that firms headquartered near terrorist attacks pay higher total compensation premia to their CEOs following the attack than before the attack or compared to firms located in safe locations.

Model (2) adds several firm-specific control variables. Firm size has a significantly positive coefficient, consistent with the results in previous studies (Gabaix and Landier, 2008 or Tervio, 2008). The coefficients on $R E T, R O A$, and $M / B$ Ratio are all significantly positive, suggesting that executives receive higher compensation when the firm performs well (Conyon, 2014). Even after adding these controls however, the coefficient on Attack Proximity is 0.108 and remains significant at the $1 \%$ level.

Model (3) adds CEO-specific characteristics. While CEO age is insignificant, CEO Ownership is significantly negative, suggesting a substitution effect between CEO stock ownership and annual compensation (consistent with Core, Holthausen, and Larcker, 1999). 
However, the coefficient on Attack Proximity continues to retain its significance. It is also economically significant. From Model (3), firms headquartered near terrorist attack locations pay about $11.5 \%$ higher $^{6}$ CEO compensation premia after the attack than those headquartered in safe locations.

Francis, Hasan, John, and Waisman (2016) show that city size also affects the level of executive compensation. Firms located in large cities, where the costs of living are higher, may pay their CEOs more. Larger cities may also attract more terrorist attacks, either because a statistically larger number of terrorists may be located in larger population centers or because terrorists may target large population centers in order to attract publicity. Since our specifications include firms from both large and small cities, the results may be driven by a positive correlation between city size, CEO compensation, and the attractiveness of large cities to terrorists. Hence, following Francis, Hasan, John, and Waisman (2016), we define Urban Agglomeration areas to include New York City, Los Angeles, Chicago, Washington, San Francisco, Philadelphia, Boston, Detroit, Dallas, and Houston. Model (4) of Table 2 shows that the interaction term between Attack Proximity and Urban Agglomeration is not statistically significant, suggesting that the effect of an attack on CEO compensation premia is present in both metropolitan and non-metropolitan firms.

In the spirit of Bertrand and Mullainathan (2003), in Model (5) of Table 2, we examine how the effect of attack proximity changes over time. Specifically, we replace the Attack Proximity indicator with seven indicator variables: Before ${ }^{-3}$, Before $^{-2}$, Before $^{-1}$, Current $_{\text {After }}{ }^{+1}$, After $^{+2}$ and $A_{f t e r}{ }^{3+}$. These variables indicate the year relative to the occurrence of the attack events. For example, Before $e^{-3}$ is a dummy that equals one if a firm-year observation is from three years (year -3) before the attack and zero otherwise, Current is a dummy that equals one if a firm-year observation

\footnotetext{
${ }^{6}$ Since the coefficient on Attack Proximity is 0.109 , and the estimated constant is 5.610, we obtain $\mathrm{e}^{(0.109+5.610)} / \mathrm{e}^{5.610}-1=11.5 \%$.
} 
is from the year (year 0) of the attack and zero otherwise, while $\mathrm{After}^{3+}$ is a dummy that equals one if a firm-year observation is at least three years after the attack and zero otherwise. The model is estimated as follows:

$\ln (\text { CEO Pay Variable })_{i t+1}=\alpha+\beta_{1}$ Before $^{-3}+\beta_{2}$ Before $^{-2}+\beta_{3}$ Before $^{-1}+\beta_{4}$ Current $+\beta_{5}$ After $^{+1}$

$+\beta_{6} \mathrm{After}^{+2}+\beta_{7} \mathrm{After}^{3+}+$ Firm and CEO characteristics Controls $+\alpha_{i}+\delta_{t}+\varepsilon i t+1$ (2)

The coefficients on Before ${ }^{-3}$, Before ${ }^{-2}$, and Before ${ }^{-1}$ are all insignificant. In contrast, the coefficient of Current is significant and positive at the $5 \%$ level while coefficients of $\mathrm{After}^{+1}$, and After $^{+2}$ are significant and positive at the $1 \%$ level, again implying that firms located near the attack location pay higher compensation to CEOs following the attack compared to firms located farther away from the attack location. The difference in the significance of the lag and lead dummies show that the results are not driven by reverse causality. In particular, this test shows that there is no evidence of an increase in compensation before the attack occurs, which provides additional confirmation that the attacks really are exogenous. Overall, the findings suggest that the increase in CEO pay is causally affected by the terrorist attack.

\subsection{PSM method}

We next construct a treatment and control group of firms using a propensity score matching (PSM) method (Rosenbaum and Rubin, 1983). For each treatment sample firm (Proximity=1), we select a matched sample firm (Proximity $=0$ ) with the closest propensity score. We match firms located near terrorist attack scenes with firms with similar characteristics located farther away from such scenes within the same state. The matching criteria include all firm characteristics that Table 1 shows are different for the two sets of firms (size, stock returns and volatility, ROA, the market-to-book ratio, cash holdings, leverage and capital expenditures), CEO characteristics (age and stockholdings), and year and industry fixed effects. To maintain the statistical independence 
of our tests, we implement a nearest neighbor matching (NNM) algorithm without replacement and match firms with similar propensity scores. The NNM algorithm uses the distance between covariate patterns to define the "closest" neighbor. In particular, each firm located near terrorist attack scenes (labeled a treatment firm) is matched to a firm located farther away from such scenes within the same state. Once a matching sample firm is selected in the control sample, it is removed from the matching pool. We keep only the firms that were matched.

Panel A of Table 3 reports parameter estimates from the probit model used to estimate propensity scores for firms in the treatment and control groups. The dependent variable is one if the firm-year belongs to the treatment group, and zero otherwise. We use the predicted probabilities or propensity scores in Column (1) to perform NNM matching. We obtain 566 unique pairs of matched firms. We next conduct a number of diagnostic tests to verify that we do not violate the parallel trends assumption in a DiD estimate. We first re-run the probit model using the matched 566 matched pairs. Column (2) of Panel A in Table 3 presents the probit estimates. None of the independent variables are statistically significant while the pseudo- $\mathrm{R}^{2}$ drops drastically to $0.53 \%$. Second, we examine the differences between the propensity scores of the treatment firms and those of the matched control firms. Panel B demonstrates that the differences are trivial. For example, the maximum distance between the two matched firms' propensity scores is only 0.001 . Finally, Panel C reports univariate comparisons between the treatment and control firms' preattack characteristics and their corresponding $t$-statistics. None of the differences are significant, implying that the characteristics of treatment and control firm groups are similar. Overall, the diagnostic tests reported in Panel A - C show that the PSM process appears to remove obvious sample selection biases, increasing the likelihood that the changes in CEO compensation are caused by an exogenous terrorist attack. 
Panel D of Table 3 presents the DiD estimators. Column (1) reports the average change in the CEO compensation for the treatment group. These measures are computed by first subtracting the CEO compensation in the pre-attack period from that in the post-attack period for each treatment firm. The differences are then averaged over the treatment group. Similarly, in Column (2), we calculate the average change in the CEO compensation for the control group. In Column (3) and (4), we report the DiD estimators and the corresponding two-tailed t-statistics testing the null hypothesis that the DiD estimators are zero. The results in Panel D show that, although the CEO compensation at both treatment and control firms increases after the attack, the increase in CEO compensation is significantly larger for the treatment group than for the control group.

Using the treatment and PSM matched control groups, we present DiD regression results in Panel E. Column (1) shows that the coefficient of Attack Proximity is 0.108 and significant at the $1 \%$ level, a result that is qualitatively very similar to those in Table 2. In Column (2), as in Model (5) of Table 2, we replace the Attack Proximity indicator with the seven indicator variables before and after the attack. Again, the coefficients on Before ${ }^{-3}$, Before $^{-2}$, and Before ${ }^{-1}$ are all insignificant, implying that the parallel trend assumption of the treatment and control groups is not violated. In contrast, the coefficient of Current, After ${ }^{+1}$, and $\mathrm{After}^{+2}$ are significant and positive, again implying that firms located near the attack location pay higher compensation to CEOs following the attack than firms located farther away from the attacks.

We note that by controlling for location fixed effects (through firm fixed effects), we control for the greatest factor in the variation in the likelihood of an attack. However, we do not control for time variation in the likelihood of an attack. The threat to our identification strategy is that CEO compensation increased in the same year as the attack because an omitted variable drove 
both the attack and the rise in CEO compensation at the same time. Though this seems unlikely to be a significant concern, we caution that our DiD methodology is not perfect.

\subsection{Alternative measures of compensation and attack proximity}

Table 4 reports results using alternative measures of compensation and attack proximity. In Panel A, we report difference-in-difference regression results using alternative measures of CEO compensation. The variable Ex Post Pay is the item TDC2 in ExecuComp. As in Table 2, Model (1) of Panel A includes Attack Proximity as the only independent variable. In Model (2) and Model (3), we add several firm-specific and CEO-specific control variables. The coefficients on Attack Proximity are $0.127,0.139$, and 0.138 , respectively, and are all statistically significant, suggesting that the pay premium for terrorist attacks is robust to using alternative measures of CEO compensation.

Panel B reports difference-in-difference regression results using alternative measures of attack proximity. In the first three columns, Attack Proximity is constructed using alternative distances of 30 miles, 50 miles, and 200 miles as cutoffs to differentiate whether the firm is affected by the terrorist attack. In the last column, we report results only using the first attack that is within 100 miles of a firm. Re-estimating Equation (1) using these alternative measures shows that the coefficients on Attack Proximity retain their significance.

Panel $\mathrm{C}$ uses $\operatorname{Ln}($ Distance) as the attack variable, instead of a dummy, to measure the intensity of exposure to the attacks. Based on the PSM matched sample in Table 3, we calculate the distance from the location of the treatment and control firms to the nearest attack location in a given year. ${ }^{7}$ Model (1) of Panel C in Table 4 includes Ln(Distance) as the only independent variable. Models

\footnotetext{
${ }^{7}$ For example, if the distance between the firm and the attack is less than 80 miles, then the distance variable takes the value of 0 prior to the attack, and $\ln (80)$ after the attack. We set the distance variable equal to 0 if the firm is not affected by the attack.
} 
(2) and (3) add several firm-specific and CEO-specific control variables. The coefficients on Ln(Distance) are all significantly negative, suggesting that firms located further from an attack location are less affected by the attack.

Table 5 reports only the coefficients on Attack Proximity from the DiD regressions in Model 3 Table 2 after varying distances to the attack and periods around the attack. As the table shows, the effect disappears around 250 miles away and within 2 years after the attack. For attacks between 150-250 miles away, the effect disappears within 1 year after the attack. In all cases, the increase in CEO compensation in year 2 is significant only at the $10 \%$ level.

Finally, we note that the definition of our primary measure of total compensation, the ExecuComp item TDC1, has changed slightly since 2006. Hence, we follow Walker (2011) to reconcile the TDC1 definitions between 1992-2005 and 2006-2013. In an untabulated test, we find our conclusions remain unchanged.

\subsection{Effects on the composition of compensation}

We next investigate whether terrorist attacks influence the composition of CEO compensation. Prior studies show that terrorist attacks can adversely affect the performance of financial markets and macroeconomic activities (Abadie and Gardeazabal, 2003; Blomberg, Hess, and Orphanides, 2004; Bandyopadhyay, Sandler, and Younas, 2014; or Chesney, Reshetar, and Karaman, 2011). Given that salaries and bonuses are more likely to be effective compensation methods for the shortterm than long-term stocks/options, it is plausible that CEOs prefer cash compensation to avoid uncertainty and bear reduced personal risks.

Table 6 presents coefficients from a difference-in-difference regression of the influence of terrorist attacks on the CEO compensation composition. Models (1) and (2) examine the effect of terrorist attacks on CEOs' cash compensation (e.g., salary and bonus). In Model (1), the coefficient 
on Attack Proximity is 0.135 and significant at the $1 \%$ level, indicating that the base salary of CEOs of companies near terrorist attacks is approximately $14.5 \%$ higher than those of CEOs in safer locations. Model (2) shows a similar significantly positive association between Attack Proximity and $\operatorname{Ln}($ Bonus). The coefficient of Attack Proximity is 0.197 , indicating a $21.8 \%$ bonus premium after an attack for CEOs of firms headquartered within a radius of 100 miles from an attack compared with those at firms in safer locations. This increased effect on bonuses relative to salaries may be driven by a trade-off between CEO preferences against shareholder interests. Although bonuses are earned annually, to some extent, performance-based or revenue target-based bonuses may be regarded as short-term performance-based incentives. Not surprisingly, Model (3) also reveals a significantly positive association between Attack Proximity and total cash compensation (cash salary plus bonus).

Models (4) to (6) use the values of restricted stock and options granted as well as long-term incentive payouts as dependent variables to measure the CEOs' equity-based compensation. None of the coefficients on Attack Proximity are significant, implying that CEOs of companies located near terrorist attacks generally do not receive an equity-based compensation premium. We sum all the forms of equity-based compensation and repeat the regression in Model (7) but the coefficient on Attack Proximity remains insignificant. Finally, in Model (8), we use the Cash to Total Compensation Ratio as the dependent variable. Again, the coefficient on Attack Proximity is significantly positive at the $1 \%$ level, suggesting that the proportion of salaries and bonuses increases significantly as a response to terrorist attacks.

Overall, our results do not show a substitution effect from risky compensation to cash compensation. The level of option-based compensation does not decrease. Instead, the results show 
that the increase in cash compensation following terrorist attacks drives the overall increases in total compensation documented earlier.

\section{Why does the compensation structure change in response to terrorist attacks?}

Prior studies have shown that terrorist attacks can adversely affect macroeconomic conditions and the performance of financial markets. A potential reduction in stock returns and the associated values of stock options may lead executives to reduce their preference for long-term incentive contracts (involving stock grants or stock options), instead displaying a preference for cash awards. Similarly, if the adverse effects on firms increase the likelihood of financial distress, the increased uncertainty caused by terrorist attacks may cause executives to adopt more conservative corporate policies. Finally, attack related uncertainty may also impact the value of a manager's human capital, which is correlated with the firm's stock performance when a large part of executive compensation is granted in the form of stock. For all these reasons, subsequent to the attack, CEOs may prefer to be granted a larger share of their compensation in the form of cash payments to avoid adverse impacts on stock-based payments.

\subsection{Do other company policies change in response to the attacks?}

We first examine if managers adopt more conservative financial policies following terrorist attacks. Dessaint and Matray (2017) document that managers of neighboring firms increase corporate cash holdings in response to hurricane events. They argue that the increases in cash holdings demonstrate an irrational response by managers who overestimate the actual risk of hurricane events. In this section, we examine the levels of cash holdings and other company financial policies, such as leverage, net working capital, R\&D, investment, accounts payable, and accounts receivable. Dessaint and Matray (2017) include firm-quarter fixed effects to account for seasonality in hurricane activity. Though a priori, terrorist attacks may appear unlikely to be 
seasonal, it can be argued that terrorist attacks are more likely to occur in larger gatherings of people (around holidays, for example). Hence, following Dessaint and Matray (2017), we retain firm-quarter observations for a seventeen-quarter window centered on the attack event quarter, and replicate our difference-in-difference analysis. Table 7 reports our results.

Panel A reports the results of financial policies in the immediate quarter $t+1$ following the terrorist attacks. Accounts payable and accounts receivable appear to slightly decrease following the attacks. No other firm policy variable is significantly affected by the attacks. Panel B examines detailed changes at the quarter level but finds no consistent effects. CEOs do not appear to adopt more conservative financial policies following an attack. Hence, our results appear less consistent with the hypothesis that managers irrationally overestimate the risk of future attacks and change their operational policies. The results also do not appear consistent with the hypothesis that the impact of conservative financial policy adoption on option values explains why CEOs prefer increases in cash compensation to option compensation. They seem more consistent with CEOs directly quantifying a non-monetary factor that affects their own life without considering the impact on the firm.

\subsection{Are shareholders affected by the attacks?}

We next investigate if a potential reduction in stock returns and the associated values of stock options might lead executives to reduce their preference for long-term incentive contracts, instead displaying a preference for cash compensation. Specifically, we examine whether terrorist attacks affect shareholder wealth. Using the PSM matched sample, we conduct an event study and compute long-term cumulative abnormal returns (CARs), defined as the monthly return to the treatment firm minus the monthly return of the PSM-matched control firm. Table 8 reports the results. Across different post-attack windows $(6,8,10$, and 12 months), we find that firms affected 
by the terrorist attack underperform relative to their matched peers. The findings show that shareholders of affected firms seem to suffer following the terrorist attack and the subsequent increase in CEO compensation. Hence, it appears plausible that rational CEOs anticipate the reduction in their equity-based compensation values and demand an increase in cash compensation.

However, several mechanisms might lie behind this effect and absent any exogenous variation in the mechanisms, it is difficult to distinguish between them. For example, the increase in pay may be due to a direct wealth transfer from shareholders to the CEO. Since there are no changes in firm policy, it appears that CEOs do not believe that the attacks are likely to impact the firm. However, it is also plausible that causality runs from the structure of pay to effort to stock returns

- that an increase in the proportion of cash-based compensation relative to stock-based compensation reduces the incentive of the CEO to work harder. Finally, it is plausible that managers are irrationally under-reacting to terrorist attacks by not changing firm policy, causing the firm's subsequent poor performance.

\section{Do more powerful CEOs obtain more pay?}

The ability of CEOs to extract higher compensation may not be uniform but related to CEO bargaining power. In this section, we examine when CEOs are able to extract compensation for changes in non-monetary factors. Specifically, we examine whether CEO power increases the ability of the CEO to earn compensation premia for negative shocks to non-monetary factors that affect the CEO's quality of life.

To analyze how CEO bargaining power affects the impact of terrorist attacks on CEO pay, we use three standard measures of CEO bargaining power taken from the corporate governance literature. Following Bebchuk, Cremers, and Peyer (2011), we use the ratio of total CEO compensation to the highest compensation earned by any other executive in the firm, the Pay Gap, 
to measure CEO power. We also use a measure of turnover that we call Excess Turnover, which is computed as the difference between Forced Turnover and Expected Forced Turnover. ${ }^{8}$ The variable Forced Turnover equals one if the age of the CEO on his or her departure is less than 60 years and zero otherwise (Coles, Daniel, and Naveen, 2014; Campbell et al., 2011). The assumption is that powerful CEOs are much less likely to make a forced departure from the firm than less powerful CEOs. Finally, we use the CEO's tenure (CEO Tenure) as a third proxy for CEO power because the ability to influence company decisions likely increases with greater tenure (Bebchuk and Fried, 2003, 2004; van Essen et al., 2015; Abernethy et al., 2015).

Table 9 reports the DiD regression results. In Column (1), the interaction term between Attack Proximity $\times$ Pay Gap is significantly positive, indicating that powerful CEOs get higher pay increases after the attack. In Column (2), the interaction term Attack Proximity $\times$ Excess Turnover is negative and significant at the 5\% level, implying that CEOs who are much less likely to be forced out, also earn a higher CEO total compensation following the attack. Similarly, in Column (3), the coefficient on the interaction term Attack Proximity $\times$ CEO Tenure is significantly positive, indicating that CEOs with longer tenures who are presumably more powerful, obtain higher pay increases.

\section{How do the attacks affect other executives and employees?}

In previous sections, we provide robust evidence that the CEOs are paid more compensation in response to the terrorist attack. We also show that more powerful CEOs obtain greater pay increases. The straightforward question is whether the extra compensation for the CEO is also correlated with higher pay for other executives and employees. The answer appears to be no.

\footnotetext{
8 To compute this variable, using the entire sample of 22,561 firm-year observations, we first compute the probability of a CEO forced turnover event, then obtain the Expected Forced Turnover as the predicted probability of Forced Turnover, and finally compute the Excess Turnover variable for each firm.
} 
Table 10 presents results from DiD regressions of the influence of terrorist attacks on other executives and employees' compensation. The variable $\operatorname{Ln}(\text { Other Executive Pay })_{i t+1}$ is measured as the natural logarithm of average executives' total pay (excluding the CEO) for firm $i$ in year $t+1$. We also examine the relation between the post-attack increase in CEO pay and the pay for other executives. Column (2) in Table 9 Panel B shows that while other executives get higher pay when the CEO is paid more, attack proximity reduces the magnitude of this increase. In Column (3), our dependent variable is $\operatorname{Ln}(\text { Employee Pay })_{i t+1}$, computed as the natural logarithm of average rank-and-file employee compensation for firm $i$ in year $t+1 .{ }^{9}$ Overall, we find that while employee salary doesn't change significantly, other executive pay appears to be negatively affected by proximity to the attacks, implying a substitution effect between CEO compensation and other executive compensation.

\section{Conclusions}

This study provides novel evidence on the effect of terrorist attacks on CEO compensation. Based on previous studies that discuss the consequences of terrorism and how terrorist attacks influence managerial emotion and corporate policies, we conjecture that such negative events influence both CEO compensation levels and compensation structure.

Using a sample of terrorist attacks from 1992 to 2013, our difference-in-difference models show that terrorist attacks cause an increase in CEO compensation. CEOs of companies located near terrorist attacks prefer higher levels of cash compensation (salary and bonus) over equitybased compensation (stocks and options) than CEOs of companies located in safer locations. While

\footnotetext{
9 When using Ln(Employee Pay) as our dependent variable, the number of observations decreases dramatically because many firms do not disclose their payment to rank-and-file employees.
} 
there is no decrease in equity-based compensation, an increase in cash compensation drives an increase in total overall compensation following terrorist attacks.

We further examine if managers adopt more conservative financial policies following terrorist attacks. We find no evidence of a change in financial policies. CEOs appear to directly quantify a non-monetary factor that affects their own life without considering the impact on the firm. Further tests find that firms affected by terrorist attacks underperform relative to their matched peers, implying that shareholders of affected firms seem to suffer following an attack and the subsequent increase in CEO compensation. Finally, we show that variations in the premia are affected by variations in the bargaining power of the $\mathrm{CEO}$, suggesting that powerful CEOs are better able to extract compensation premia in response to negative shocks to non-monetary factors that potentially affect their quality of life. We find no such premium for other executives and rank-andfile employees.

Our study enhances our understanding of how specific non-monetary factors affect CEO compensation and how risk affects $\mathrm{CEO}$ compensation. Our study extends the literature of the micro-impact of terrorist attacks by showing that terrorist attacks also significantly impact executive compensation policy. 


\section{References}

Abadie, A., 2006. Poverty, political freedom, and the roots of terrorism. American Economic Review 96, 50-56.

Abadie, A., Gardeazabal, J., 2003. The economic costs of conflict: A case-control study for the Basque country. American Economic Review 93, 113-132.

Abadie, A., Gardeazabal, J., 2008. Terrorism and the world economy. European Economic Review 52, 1-27.

Abernethy, M.A., Kuang, Y.F., Qin, B., 2015. The influence of CEO power on compensation contract design. The Accounting Review 90, 1265-1306.

Ahern, K.R., 2012. The importance of psychology in economic activity: Evidence from terrorist attacks, working paper, available at SSRN: https://papers.ssrn.com/sol3/papers.cfm?abstract_id=2085013.

Antoniou, C., Kumar, A., Maligkris, A., 2016a. Terrorist attacks, sentiment, and corporate policies, working paper, available at SSRN: https://ssrn.com/abstract $=2566740$.

Antoniou, C., Kumar, A., Maligkris, A., 2016b. Terrorist attacks, analyst sentiment, and earnings forecasts, working paper, available at SSRN: https://papers.ssrn.com/sol3/papers.cfm?abstract_id=2702051.

Arin, K.P., Ciferri, D., Spagnolo, N., 2008. The price of terror: The effects of terrorism on stock market returns and volatility. Economics Letters 101, 164-167.

Bandyopadhyay, S., Sandler, T., Younas, J., 2014. Foreign direct investment, aid, and terrorism. Oxford Economic Papers 66, 25-50.

Bebchuk, L.A., Cremers K.J.M., Peyer, U.C., 2011. The CEO pay slice. Journal of Financial Economics 102, 199-221.

Bebchuk, L.A., Fried, J. M., 2003. Executive compensation as an agency problem. Journal of Economic Perspectives 17, 71-92.

Bebchuk, L.A., Fried, J.M., 2004. Pay without performance: The unfulfilled promise of executive compensation. Cambridge, MA: Harvard University Press.

Bertrand, M., Duflo, E., Mullainathan, S., 2004. How much should we trust Differences-inDifferences estimates? Quarterly Journal of Economics 119, 249-275.

Bertrand, M., Mullainathan, S., 2003. Enjoying the quiet life? Corporate governance and managerial preference. Journal of Political Economy 111, 1043-1075. 
Black, F., Scholes, M., 1973. The pricing of options and corporate liabilities. Journal of Political Economy 81, 637-654.

Blomberg, S.B., Hess, G. D., Orphanides, A., 2004. The macroeconomic consequences of terrorism. Journal of Monetary Economics 51, 1007-1032.

Brounen, D., Derwall, J., 2010. The impact of terrorist attacks on international stock markets. European Financial Management 16, 585-598.

Campbell, T.C., Gallmeyer, M., Johnson, S.A., Rutherford, J., Stanley, B.W., 2011. CEO optimism and forced turnover. Journal of Financial Economics 101, 695-712.

Chen, A.H., Siems, T.F., 2004. The effects of terrorism on global capital markets. European Journal of Political Economy 20, 349-366.

Cheng, Y., Liu, B. McConnell, J.J., Rosenblum, A., 2017. When is good news bad and vice versa? The fortune rankings of America's most admired companies. Journal of Corporate Finance 43, 378-396.

Chesney, M., Reshetar, G., Karaman, M., 2011. The impact of terrorism on financial markets: An empirical study. Journal of Banking and Finance 35, 253-267.

Coles, J.L., Daniel, N.D., Naveen, L., 2014. Co-opted boards. Review of Financial Studies 27, 1751-1769.

Conyon, M.J., 2014. Executive compensation and board governance in US firms. The Economic Journal 124, 60-89.

Core, J.E., Holthausen, R.W., Larcker, D.F., 1999. Corporate governance, chief executive officer compensation, and firm performance. Journal of Financial Economics 51, 371-406.

Cyert, R., Kang, S., Kumar, P., Shah, A., 1997. Corporate governance and the level of CEO compensation, working paper, Carnegie Mellon University.

Deng, X., Gao, H., 2013. Nonmonetary benefits, quality of life, and executive compensation. Journal of Financial and Quantitative Analysis 48, 197-218.

Dessaint, O., Matray, A., 2017. Do managers overreact to salient risks? Evidence from hurricane strikes. Journal of Financial Economics 126, 97-121.

Di Tella, R., Schargrodsky, E., 2004. Do police reduce crime? Estimates using the allocation of police forces after a terrorist attack. American Economic Review 94, 115-133.

Eckstein, Z., Tsiddon, D., 2004. Macroeconomic consequences of terror: Theory and the case of Israel. Journal of Monetary Economics 51, 971-1002.

Focke, F., Maug, E., Niessen-Ruenzi, A., 2017. The impact of firm prestige on executive compensation. Journal of Financial Economics 123, 313-336. 
Francis, B.B., Hasan, I., John, K., Waisman, M., 2016. Urban agglomeration and CEO compensation. Journal of Financial and Quantitative Analysis 51, 1925-1953.

Gabaix, X., Landier, A., 2008. Why has CEO pay increased so much? Quarterly Journal of Economics 123, 49-100.

Gibbons, R., Murphy, K.J., 1992. Optimal incentive contracts in the presence of career concerns: Theory and evidence. Journal of Political Economy 100, 468-505.

Gould, E.D., Stecklov, G., 2009. Terror and the costs of crime. Journal of Public Economics 93, 1175-1188.

Guan, X., Li, O.Z., Xu, H., 2016. The audit pricing of terrorism. working paper, available at SSRN: https://papers.ssrn.com/sol3/papers.cfm?abstract_id=2773490.

Harris, M., Raviv, A., 1979. Optimal incentive contracts with imperfect information. Journal of Economic Theory 20, 231-259.

Kaplan, S. N., Rauh, J. D., 2010. Wall street and main street: What contributes to the rise in the highest incomes? Review of Financial Studies 23, 1004-1050.

Karolyi, G.A., Martell, R., 2010. Terrorism and the stock market. International Review of Applied Financial Issues and Economics 2, 285-314.

Kollias, C., Papadamou, S., Stagiannis, A., 2011. Terrorism and capital markets: The effects of the Madrid and London bomb attacks. International Review of Economics and Finance 20, 532-541.

Metcalfe, R., Powdthavee, N., Dolan, P., 2011. Destruction and distress: Using a quasiexperiment to show the effects of the September 11 attacks on mental well-being in the United Kingdom. The Economic Journal 121, 81-103.

Michel-Kerjan, E., Pedell, B., 2006. How does the corporate world cope with mega-terrorism? Puzzling evidence from terrorism insurance markets. Journal of Applied Corporate Finance $18,61-75$.

Miller, E., 2016. Patterns of Terrorism in the United States, 1970-2014. Report to the Office of University Programs, Science and Technology Directorate, U.S. Department of Homeland Security, START College Park, MD.

Nikkinen, J., Vähämaa, S., 2010. Terrorism and stock market sentiment. Financial Review 45, 263-275.

Peters, F. S., Wagner, A. F., 2014. The executive turnover risk premium. Journal of Finance 69, 1529-1563.

Procasky, W.J., Ujah, N.U., 2016. Terrorism and its impact on the cost of debt. Journal of International Money and Finance 60, 253-266. 
PwC, 2016. The $19^{\text {th }}$ Annual Global CEO Survey. Retrieved from website: www.pwc.com/gx/en/ceo-survey/.

Rau, R., 2015. Executive compensation. Foundations and Trends in Finance 10, 181-363.

Rosenbaum, P.R., Rubin, D.B., 1983. The central role of the propensity score in observational studies for causal effects. Biometrika 70, 41-55.

START, 2016. National Consortium for the Study of Terrorism and Responses to Terrorism (START). Global Terrorism Database [Data file]. Retrieved from https://www.start.umd.edu/gtd/.

Tervio, M., 2008. The Difference that CEOs make: An assignment model approach. American Economic Review 98, 642-668.

van Essen, M., Otten, J., Carberry, E.J., 2015. Assessing managerial power theory: A metaanalytic approach to understanding the determinants of CEO compensation. Journal of Management 41, 164-202.

Vincenty, T., 1975. Direct and inverse solutions of geodesics on the ellipsoid with application of nested equations. Survey Review 23, 88-93.

Walker, D.I., 2011. Evolving executive equity compensation and the limits of optimal contracting. Vanderbilt Law Review 64, 609-674.

Yim, S., 2013. The acquisitiveness of youth: CEO age and acquisition behaviour. Journal of Financial Economics 108, 250-273.

Yonker, S. E., 2016. Geography and the market for CEOs. Management Science 63, 609-630. 


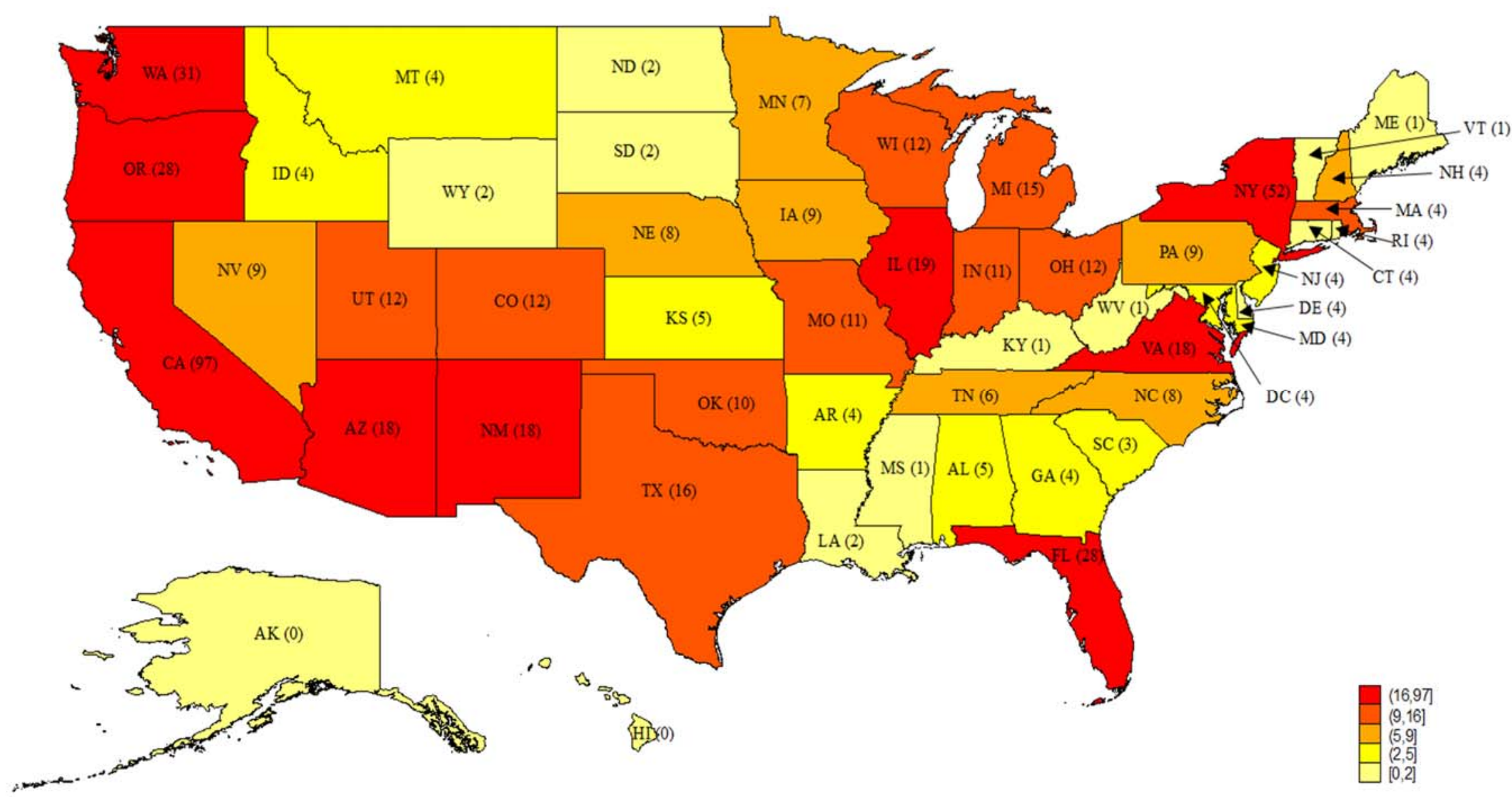

Fig. 1. Distribution of attacks by state 


\section{Appendix A: Terrorist Attack Events Description}

This table presents descriptive statistics of terrorist events from 1992 - 2013. Panel A presents the distribution by attack type and Panel B presents the frequency of terrorist attacks by year.

Panel A: Distribution by Attack Type

\begin{tabular}{lcr}
\hline Attack type & Frequency & Percent \\
\hline Armed Assault & 48 & 8.44 \\
Assassination & 21 & 3.69 \\
Bombing/Explosion & 138 & 24.25 \\
Facility/Infrastructure Attack & 296 & 52.02 \\
Hijacking & 6 & 1.05 \\
Hostage Taking (Barricade Incident) & 14 & 2.46 \\
Hostage Taking (Kidnapping) & 3 & 0.53 \\
Unarmed Assault & 42 & 7.38 \\
Unknown & 1 & 0.18 \\
Total & 569 & 100 \\
\hline
\end{tabular}

Panel B: Distribution by Year

\begin{tabular}{lrc}
\hline Year & No. of Attacks & Proportion of total \\
\hline 1992 & 31 & 5.45 \\
1993 & 0 & 0.00 \\
1994 & 56 & 9.84 \\
1995 & 62 & 10.9 \\
1996 & 36 & 6.33 \\
1997 & 39 & 6.85 \\
1998 & 26 & 4.57 \\
1999 & 53 & 9.31 \\
2000 & 33 & 5.80 \\
2001 & 39 & 6.85 \\
2002 & 33 & 5.80 \\
2003 & 32 & 5.62 \\
2004 & 9 & 1.58 \\
2005 & 23 & 4.04 \\
2006 & 6 & 1.05 \\
2007 & 9 & 1.58 \\
2008 & 19 & 3.34 \\
2009 & 11 & 1.93 \\
2010 & 17 & 2.99 \\
2011 & 9 & 1.58 \\
2012 & 12 & 2.11 \\
2013 & 14 & 2.46 \\
Total & 569 & 100 \\
\hline
\end{tabular}




\section{Appendix B: Variable definitions}

\begin{tabular}{ll}
\hline Variable & Definition \\
\hline Attack Proximity Variables & \\
Attack Proximity & $\begin{array}{l}\text { Dummy variable that takes value } 1 \text { for affected firms after a terrorist } \\
\text { attack has occurred, and zero prior to the event. The affected firms } \\
\text { are those firms that are headquartered within } 100 \text { miles of the } \\
\text { location of the terrorist events and at least three years have elapsed } \\
\text { since the last attack. }\end{array}$
\end{tabular}

\section{Pay Variables \\ Total Pay}

Ex Post Pay

Salary

Bonus

Option Value

Stock Value

LTIP Value

Equity based pay

Cash to total compensation ratio

\section{Firm Characteristics Variables \\ Firm Size \\ Volatility \\ RET \\ $R O A$}

Cash/Assets

Leverage

Capex/Assets
M/B Ratio

Item TDC1 in ExecuComp that consists of salary, bonus, value of restricted stocks granted, value of options granted, long-term incentive payouts, and other types of compensation Item TDC2 in ExecuComp that is similar to TDC1, except that it replaces the value of options granted with the value of options exercised during the given year

Value of salary (item SALARY in ExecuComp, \$M)

Value of bonus (item BONUS in ExecuComp, \$M)

Value of options granted using Black-Scholes (item

OPTION_AWARDS_BLK_VALUE in ExecuComp, \$M)

Value of restricted stocks granted (item RSTKGRNT in ExecuComp, $\$ \mathrm{M})$

Value of long-term incentive payouts (item LTIP in ExecuComp, $\$ \mathrm{M})$

Sum of option value, stock value and LTIP value

Sum of salary and bonus divided by total compensation

Natural logarithm of total assets from Compustat (item AT in Compustat)

Standard deviation of the firm's monthly stock returns over the previous 5-year period

Buy-and-hold return on a firm's stock for the past 12 months

Net income before extraordinary items and discontinued operations divided by total assets (item IB/AT in Compustat)

Market value of equity divided by book value of equity, where the market value is obtained as the fiscal year closing price multiplied by common shares outstanding (item $\mathrm{PRC} \times$ SHROUT/CEQ in Compustat)

Ratio of cash items to total assets (item CHE/AT in Compustat) Sum of current liabilities and long-term debt divided by total assets (item (DLT+DLTT)/AT in Compustat)

Ratio of capital expenditures to total assets (item CAPX/AT in Compustat)

\section{CEO Characteristics}

CEO Age
Age of the executive in ExecuComp 
CEO Ownership

\section{Neighborhood Characteristics}

Urban Agglomeration
Ratio of shares owned by the CEO, excluding options owned, to shares outstanding (item SHROWN_TOT_PCT in ExecuComp)

Dummy variable with the value of 1 if the firm is headquartered in New York City, Los Angeles, Chicago, Washington, San Francisco, Philadelphia, Boston, Detroit, Dallas, or Houston CMSA, following Francis, Hasan, John, and Waisman (2016).

\section{Other Executives and Employee Pay variables}

Other Executive Pay

Other Executive Age

Other Executive Ownership

Employee Pay

\section{CEO Power Variables}

Pay Gap

Excess Turnover
Average executive total pay measured as item TDC1 in ExecuComp, excluding the CEO.

Average executive age, excluding the CEO.

Average ratio of shares owned by executives, excluding the CEO (item SHROWN_TOT_PCT in ExecuComp).

Average compensation earned by all employees (excluding the executives disclosed in corporate filings). (item XLR in Compustat)

Ratio of total CEO compensation to the highest compensation earned by any other executive in the firm.

Computed as the difference between Forced Turnover and Expected Forced Turnover. The variable Forced Turnover, equals one if the age of the $\mathrm{CEO}$ on his or her departure is less than 60 years and zero otherwise. We first examine the probability of a CEO forced turnover event, then obtain the Expected Forced Turnover as the predicted probability of Forced Turnover, and compute the Excess Turnover. Natural logarithm of CEO's tenure plus 1 


\section{Table 1. Summary statistics}

This table presents summary statistics for the main variables. All variables are defined in Appendix B. Column (a) reports mean and median values for the firm-years before the terrorist attacks for all firms affected by the attacks. Column (b) reports mean and median values for the firm-years after the terrorist attacks for all firms affected by the attacks. Column (c) reports mean and median values for the firm-years of control firms who are not affected by a terrorist attack. Columns (d) and (e) report results from mean and median difference tests between column (a) and (c) and column (b) and (c), respectively. ${ }^{* *}$, and $* * *$ represent significance at the $10 \%, 5 \%$, and $1 \%$ levels, respectively.

\begin{tabular}{|c|c|c|c|c|c|c|c|c|c|c|}
\hline \multirow[b]{3}{*}{ Variable } & \multicolumn{4}{|c|}{ Treated Group } & \multirow{2}{*}{\multicolumn{2}{|c|}{$\begin{array}{l}\text { Control Group } \\
\text { (c) }\end{array}$}} & \multirow{2}{*}{\multicolumn{2}{|c|}{$\begin{array}{l}\text { (a) vs. (c) } \\
\text { (d) }\end{array}$}} & \multirow{2}{*}{\multicolumn{2}{|c|}{$\begin{array}{c}\text { (b) vs. (c) } \\
\text { (e) }\end{array}$}} \\
\hline & \multicolumn{2}{|c|}{$\begin{array}{l}\text { Before attack } \\
\text { (a) }\end{array}$} & \multicolumn{2}{|c|}{$\begin{array}{l}\text { After attack } \\
\text { (b) }\end{array}$} & & & & & & \\
\hline & Mean & Median & Mean & Median & Mean & Median & Mean & Median & Mean & Median \\
\hline \multicolumn{11}{|l|}{ Compensation } \\
\hline Total Pay $_{t+1}(\$ M)$ & 5.866 & 3.864 & 7.296 & 5.092 & 5.288 & 3.293 & $0.578 * * *$ & $0.571 * * *$ & $2.008 * * *$ & $1.799 * * *$ \\
\hline Salary $_{t+1}(\$ M)$ & 0.937 & 0.900 & 1.031 & 0.992 & 0.851 & 0.788 & $0.086^{* * *}$ & $0.112 * * *$ & $0.180 * * *$ & $0.204 * * *$ \\
\hline Bonus $_{t+1}(\$ M)$ & 0.707 & 0.158 & 0.945 & 0.272 & 0.606 & 0.017 & $0.101 * * *$ & $0.141 * * *$ & $0.339 * * *$ & $0.255^{* * *}$ \\
\hline Cash-based pay $_{t+1}(\$ M)$ & 1.644 & 1.134 & 1.976 & 1.302 & 1.457 & 1.002 & $0.187 * * *$ & $0.132 * * *$ & $0.519 * * *$ & $0.300 * * *$ \\
\hline Option Value $_{t+1}(\$ M)$ & 2.336 & 0.672 & 2.837 & 1.071 & 2.147 & 0.575 & $0.189^{*}$ & $0.097 * * *$ & $0.690 * * *$ & $0.496 * * *$ \\
\hline Stock Value $_{t+1}(\$ M)$ & 0.472 & 0.001 & 0.638 & 0.001 & 0.409 & 0.001 & $0.063 * *$ & $0.000 * * *$ & $0.229 * * *$ & $0.000 * * *$ \\
\hline LTIP Value $_{t+1}(\$ M)$ & 0.214 & 0.001 & 0.276 & 0.001 & 0.178 & 0.001 & $0.036 * *$ & 0.000 & $0.098 * * *$ & $0.000 * * *$ \\
\hline Equity-based pay ${ }_{t+1}(\$ M)$ & 3.227 & 1.142 & 4.027 & 1.775 & 2.912 & 0.966 & $0.315 * *$ & $0.176^{* * *}$ & $1.115^{* * *}$ & $0.809^{* * *}$ \\
\hline Cash to total compensation ratio $_{t+1}$ & 0.860 & 0.858 & 0.871 & 0.871 & 0.855 & 0.856 & $0.005 * *$ & 0.002 & $0.016 * * *$ & $0.015 * * *$ \\
\hline Other Executive Pay ${ }_{t+1}(\$ M)$ & 2.435 & 1.486 & 2.945 & 1.934 & 2.156 & 1.336 & $0.279 * * *$ & $0.150 * * *$ & $0.789 * * *$ & $0.598 * * *$ \\
\hline Employee Pay ${ }_{t+1}(\$ M)$ & 0.094 & 0.080 & 0.103 & 0.084 & 0.077 & 0.071 & $0.010 * * *$ & $0.006 * * *$ & $0.019 * * *$ & $0.010 * * *$ \\
\hline \multicolumn{11}{|l|}{ Firm Characteristics } \\
\hline Firm size $_{t}$ & 8.071 & 8.022 & 8.522 & 8.464 & 7.821 & 7.695 & $0.250 * * *$ & $0.327 * * *$ & $0.701 * * *$ & $0.769 * * *$ \\
\hline Volatility $_{t}$ & 0.104 & 0.092 & 0.105 & 0.092 & 0.119 & 0.107 & $-0.015 * * *$ & $-0.015 * * *$ & $-0.014 * * *$ & $-0.015 * * *$ \\
\hline$R E T[-12,0]_{t}$ & 0.159 & 0.123 & 0.148 & 0.115 & 0.161 & 0.114 & -0.002 & 0.009 & -0.013 & 0.001 \\
\hline$R O A_{t}$ & 0.048 & 0.050 & 0.046 & 0.048 & 0.040 & 0.042 & $0.008 * * *$ & $0.008 * * *$ & $0.006 * * *$ & $0.006 * * *$ \\
\hline M/B Ratio ${ }_{t}$ & 3.177 & 2.332 & 3.429 & 2.424 & 2.800 & 2.078 & $0.377 * * *$ & $0.254 * * *$ & $0.629 * * *$ & $0.346^{* * *}$ \\
\hline Cash/Assets $_{t}$ & 0.121 & 0.064 & 0.117 & 0.066 & 0.136 & 0.069 & $-0.015 * * *$ & $-0.005^{* * *}$ & $-0.019 * * *$ & $-0.003 * * *$ \\
\hline Leverage $_{t}$ & 0.346 & 0.313 & 0.351 & 0.322 & 0.358 & 0.303 & $-0.012 *$ & 0.010 & -0.007 & $0.019^{*}$ \\
\hline Capex/Assets $_{t}$ & 0.047 & 0.036 & 0.046 & 0.037 & 0.052 & 0.036 & $-0.005 * * *$ & 0.000 & $-0.006 * * *$ & 0.001 \\
\hline
\end{tabular}




\section{CEO Characteristics}

CEO Age
CEO Ownership

$56.488 \quad 57.000$

$56.713 \quad 57.000$

$55.986 \quad 56.000$

$0.502 * * *$

$1.000 * * *$

$0.727 * * *$

$1.000 * * *$ 1.948

0.069

$1.619 \quad 0.035$

2.032

$0.200 \quad-0.084$

$-0.131 * * *$

$-0.413 * * *$

$-0.165 * * *$ 


\section{Table 2. Effect of terrorist attacks on the level of CEO compensation}

This table presents coefficients from difference-in-difference (DiD) regressions of the effect of terrorist attacks on executive compensation. The dependent variable is $L n(\text { Total Pay })_{t+1}$. The treatment group includes all firms that are affected by the attacks that have occurred at time $t$, specifically, firms that are headquartered within 100 miles of the location of the terrorist events and at least three years have elapsed since the last attack. The control group includes the treatment firms before time $t$ and all remaining firms. Before ${ }^{-t}$ is a dummy variable equal to 1 in the year $t$ before the attack if the county of the firm headquarters is in the area hit by an attack during year $t$. After ${ }^{+t}$ is defined similarly for the year $t(t=1,2)$ after the attack. After ${ }^{3+}$ is a dummy that equals one if a firm-year observation is at least three years after the attack and zero otherwise. All other variables are defined in Appendix B. $P$-values clustered by firm and year are in parentheses. *, **, and *** represent significance at the $10 \%, 5 \%$, and $1 \%$ levels, respectively.

\begin{tabular}{|c|c|c|c|c|c|}
\hline & (1) & (2) & (3) & (4) & $(5)$ \\
\hline Attack Proximity & $\begin{array}{c}0.099 * * * \\
(0.000)\end{array}$ & $\begin{array}{c}0.108 * * * \\
(0.000)\end{array}$ & $\begin{array}{c}0.109 * * * \\
(0.000)\end{array}$ & $\begin{array}{c}0.117 * * * \\
(0.000)\end{array}$ & \\
\hline Attack Proximity $\times$ Urban Agglomeration & & & & $\begin{array}{c}-0.054 \\
(0.228)\end{array}$ & \\
\hline Before $^{-3}$ & & & & & $\begin{array}{l}-0.012 \\
(0.756)\end{array}$ \\
\hline Before $^{-2}$ & & & & & $\begin{array}{c}-0.010 \\
(0.768)\end{array}$ \\
\hline Before $^{-1}$ & & & & & $\begin{array}{l}-0.042 \\
(0.151)\end{array}$ \\
\hline Current & & & & & $\begin{array}{c}0.090^{* *} \\
(0.017)\end{array}$ \\
\hline After $^{+1}$ & & & & & $\begin{array}{c}0.153^{* * *} * \\
(0.000)\end{array}$ \\
\hline After ${ }^{+2}$ & & & & & $\begin{array}{c}0.101 * * * \\
(0.001)\end{array}$ \\
\hline After ${ }^{3+}$ & & & & & $\begin{array}{c}0.044 \\
(0.229)\end{array}$ \\
\hline Firm characteristics & & & & & \\
\hline Firm size & & $\begin{array}{c}0.247 * * * \\
(0.000)\end{array}$ & $\begin{array}{c}0.246 * * * \\
(0.000)\end{array}$ & $\begin{array}{c}0.246^{* * *} \\
(0.000)\end{array}$ & $\begin{array}{c}0.245^{* * *} \\
(0.000)\end{array}$ \\
\hline Volatility & & $\begin{array}{c}0.047 \\
(0.863)\end{array}$ & $\begin{array}{c}0.078 \\
(0.777)\end{array}$ & $\begin{array}{c}0.078 \\
(0.777)\end{array}$ & $\begin{array}{c}0.074 \\
(0.787)\end{array}$ \\
\hline $\operatorname{RET}_{[-12,0]}$ & & $\begin{array}{c}0.147 * * * \\
(0.000)\end{array}$ & $\begin{array}{c}0.148 * * * \\
(0.000)\end{array}$ & $\begin{array}{c}0.148^{* * *} \\
(0.000)\end{array}$ & $\begin{array}{c}0.148^{* * *} \\
(0.000)\end{array}$ \\
\hline$R O A$ & & $\begin{array}{c}0.459^{* * *} \\
(0.000)\end{array}$ & $\begin{array}{c}0.461 * * * \\
(0.000)\end{array}$ & $\begin{array}{c}0.461 * * * \\
(0.000)\end{array}$ & $\begin{array}{c}0.462 * * * \\
(0.000)\end{array}$ \\
\hline M/B Ratio & & $\begin{array}{c}0.021 * * * \\
(0.000)\end{array}$ & $\begin{array}{c}0.021 * * * \\
(0.000)\end{array}$ & $\begin{array}{c}0.021 * * * \\
(0.000)\end{array}$ & $\begin{array}{c}0.021 * * * \\
(0.000)\end{array}$ \\
\hline Cash/Assets & & $\begin{array}{l}-0.056 \\
(0.451)\end{array}$ & $\begin{array}{l}-0.059 \\
(0.432)\end{array}$ & $\begin{array}{l}-0.059 \\
(0.432)\end{array}$ & $\begin{array}{c}-0.056 \\
(0.457)\end{array}$ \\
\hline Leverage & & $\begin{array}{c}-0.229 * * * \\
(0.000)\end{array}$ & $\begin{array}{c}-0.228 * * * \\
(0.000)\end{array}$ & $\begin{array}{c}-0.228 * * * \\
(0.000)\end{array}$ & $\begin{array}{c}-0.225 * * * \\
(0.000)\end{array}$ \\
\hline Capex/Assets & & $\begin{array}{c}0.248 \\
(0.233)\end{array}$ & $\begin{array}{c}0.253 \\
(0.225)\end{array}$ & $\begin{array}{c}0.253 \\
(0.226)\end{array}$ & $\begin{array}{c}0.262 \\
(0.209)\end{array}$ \\
\hline
\end{tabular}




\begin{tabular}{|c|c|c|c|c|c|}
\hline \multicolumn{6}{|l|}{ CEO characteristics } \\
\hline \multirow{2}{*}{\multicolumn{3}{|c|}{ CEO Age }} & -0.001 & -0.001 & -0.001 \\
\hline & & & $(0.197)$ & $(0.193)$ & $(0.199)$ \\
\hline \multirow{2}{*}{\multicolumn{3}{|c|}{ CEO Ownership }} & $-0.005 * *$ & $-0.005 * *$ & $-0.005 * *$ \\
\hline & & & $(0.028)$ & $(0.029)$ & $(0.028)$ \\
\hline Intercept & Yes & Yes & Yes & Yes & Yes \\
\hline Year Fixed Effects & Yes & Yes & Yes & Yes & Yes \\
\hline Firm Fixed Effects & Yes & Yes & Yes & Yes & Yes \\
\hline Clustered by firm and year & Yes & Yes & Yes & Yes & Yes \\
\hline Obs & 22,561 & 22,561 & 22,561 & 22,561 & 22,561 \\
\hline Adj. $R^{2}$ & 0.7006 & 0.7189 & 0.7192 & 0.7192 & 0.7194 \\
\hline
\end{tabular}


Table 3. PSM results

This table reports coefficients from difference-in-difference (DiD) tests examining the effect of terrorist attacks on executive compensation. The treatment group consists of firms affected by the attack, as defined in Table 2, while the control group consists of firms in the same state but not affected by the attacks. We match firms using one-to-one nearest neighbor propensity score matching, without replacement. Panel A presents parameter estimates from the probit model used to estimate propensity scores for firms in the treatment and control groups. The dependent variable is one if the firm-year belongs to the treatment group, and zero otherwise. Industry fixed effects are included in both columns in Panel A. Panel B reports the distribution of estimated propensity scores for the treatment firms, control firms, and the difference in estimated post-matched propensity scores. Panel $\mathrm{C}$ reports univariate comparisons between the treatment and control firms' characteristics and their corresponding $t$-statistics. Panel D reports differences in compensation changes before and after the attack, between treatment and control groups. Panel E reports coefficients from DiD regressions. Before ${ }^{-t}$ and After ${ }^{+t}$ dummies are defined as in Table 2. All other variables are defined in Appendix B. $P$-values are in parentheses. $*$, **, and $* * *$ represent significance at the $10 \%, 5 \%$, and $1 \%$ levels, respectively.

Panel A: Pre-match propensity score regression and post-match diagnostic regression

\begin{tabular}{|c|c|c|}
\hline \multirow[t]{3}{*}{ Dependent variable } & \multicolumn{2}{|c|}{ Dummy $=1$ if in treatment group; 0 if in control group } \\
\hline & (1) & (2) \\
\hline & Pre-match & Post-match \\
\hline \multicolumn{3}{|l|}{ Firm characteristics } \\
\hline \multirow[t]{2}{*}{ Firm size $_{t-1}$} & $0.101 * * *$ & 0.017 \\
\hline & $(0.005)$ & $(0.693)$ \\
\hline \multirow[t]{2}{*}{ Volatility $_{t-1}$} & $-4.170 * * *$ & -0.108 \\
\hline & $(0.001)$ & $(0.942)$ \\
\hline \multirow[t]{2}{*}{$R E T_{[-12,0]} t-1$} & $0.232 *$ & -0.043 \\
\hline & $(0.063)$ & $(0.777)$ \\
\hline \multirow{2}{*}{$R O A_{t-1}$} & -0.142 & -0.513 \\
\hline & $(0.807)$ & $(0.550)$ \\
\hline \multirow[t]{2}{*}{ M/B Ratio ${ }_{t-1}$} & $0.086^{* * *}$ & -0.025 \\
\hline & $(0.000)$ & $(0.309)$ \\
\hline \multirow[t]{2}{*}{ Cash/Assets $_{t-1}$} & $-1.044 * *$ & -0.211 \\
\hline & $(0.013)$ & $(0.671)$ \\
\hline \multirow{2}{*}{ Leverage $_{t-1}$} & $-0.495 * * *$ & 0.081 \\
\hline & $(0.008)$ & $(0.731)$ \\
\hline \multirow[t]{2}{*}{ Capex/Assetst-1 } & -0.693 & 0.226 \\
\hline & $(0.583)$ & $(0.884)$ \\
\hline \multicolumn{3}{|l|}{ CEO characteristics } \\
\hline \multirow{2}{*}{ CEO Age $e_{t-1}$} & 0.003 & 0.000 \\
\hline & $(0.689)$ & $(0.989)$ \\
\hline \multirow[t]{2}{*}{ CEO Ownership $t_{t-1}$} & 0.002 & -0.007 \\
\hline & $(0.845)$ & $(0.564)$ \\
\hline Intercept & Yes & Yes \\
\hline Industry Fixed Effects & Yes & Yes \\
\hline Obs & 2,168 & 1,132 \\
\hline Pseudo $R^{2}$ & 0.0908 & 0.0053 \\
\hline
\end{tabular}


Panel B: Estimated propensity score distributions

\begin{tabular}{lcccccccc}
\hline $\begin{array}{l}\text { Propensity } \\
\text { Scores }\end{array}$ & $\begin{array}{c}\text { No. of } \\
\text { Obs. }\end{array}$ & Min & p5 & p50 & Mean & SD & P95 & Max \\
\hline Treatment & 566 & 0.038 & 0.133 & 0.335 & 0.332 & 0.125 & 0.534 & 0.651 \\
Control & 566 & 0.038 & 0.133 & 0.335 & 0.338 & 0.135 & 0.578 & 0.751 \\
Difference & - & -0.100 & -0.043 & 0.000 & -0.005 & 0.018 & 0.000 & 0.001 \\
\hline
\end{tabular}

Panel C: Differences in firm characteristics before attacks occur

\begin{tabular}{lcccc}
\hline Variable & Treatment & Control & Difference & t-statistic \\
\hline Firm size $_{t-1}$ & 7.979 & 7.936 & 0.043 & 0.433 \\
Volatility $_{t-1}$ & 0.111 & 0.112 & -0.000 & -0.012 \\
RET $_{[-12,0]} t-1$ & 0.084 & 0.102 & -0.017 & -0.689 \\
ROA $_{t-1}$ & 0.044 & 0.048 & -0.005 & -1.012 \\
M/B Ratio $t-1$ & 2.982 & 3.180 & -0.198 & -1.213 \\
Cash/Assets $_{t-1}$ & 0.132 & 0.136 & -0.004 & -0.472 \\
Leverage $_{t-1}$ & 0.338 & 0.331 & 0.007 & 0.379 \\
Capex/Assets $_{t-1}$ & 0.049 & 0.050 & -0.001 & -0.458 \\
CEO Age & 56.500 & 56.527 & -0.027 & -0.063 \\
CEO Ownership & & 2.282 & -0.237 & -0.745 \\
\hline
\end{tabular}

Panel D: Difference in CEO pay from before to after the attack

\begin{tabular}{ccccc}
\hline & $\begin{array}{c}\text { Mean Treatment } \\
\text { Difference } \\
\text { (After - Before) }\end{array}$ & $\begin{array}{c}\text { Mean Control } \\
\text { Difference } \\
\text { (After - Before) }\end{array}$ & $\begin{array}{c}\text { Mean DiD } \\
\text { Estimator } \\
\text { (Treat - Control) }\end{array}$ & $\begin{array}{c}t \text {-statistic for DiD } \\
\text { Estimator }\end{array}$ \\
\hline Ln(Total Pay $)_{t+1}$ & $(1)$ & $(2)$ & $(3)$ & $(4)$ \\
& $0.435^{* * *}$ & $0.240^{* * *}$ & $0.195^{* * *}$ & 5.351 \\
& $(0.024)$ & $(0.029)$ & $(0.037)$ & \\
\hline
\end{tabular}


Panel E: DiD regression with PSM matched sample

\begin{tabular}{|c|c|c|}
\hline \multirow[t]{2}{*}{ Dependent variable } & \multicolumn{2}{|c|}{ Ln(Total Pay $)_{t+1}$} \\
\hline & (1) & (2) \\
\hline Attack Proximity & $\begin{array}{c}0.108^{* * *} * \\
(0.000)\end{array}$ & \\
\hline Before $^{-3}$ & & $\begin{array}{l}-0.018 \\
(0.676)\end{array}$ \\
\hline Before ${ }^{-2}$ & & $\begin{array}{l}-0.013 \\
(0.715)\end{array}$ \\
\hline Before ${ }^{-1}$ & & $\begin{array}{l}-0.036 \\
(0.213)\end{array}$ \\
\hline Current & & $\begin{array}{c}0.087 * * \\
(0.014)\end{array}$ \\
\hline After +1 & & $\begin{array}{c}0.168 * * * \\
(0.000)\end{array}$ \\
\hline After +2 & & $\begin{array}{c}0.094 * * * \\
(0.006)\end{array}$ \\
\hline After ${ }^{3+}$ & & $\begin{array}{c}0.033 \\
(0.361)\end{array}$ \\
\hline Firm characteristics & & \\
\hline Firm size & $\begin{array}{c}0.250 * * * \\
(0.000)\end{array}$ & $\begin{array}{c}0.248 * * * \\
(0.000)\end{array}$ \\
\hline Volatility & $\begin{array}{c}0.144 \\
(0.696)\end{array}$ & $\begin{array}{c}0.140 \\
(0.702)\end{array}$ \\
\hline$R E T_{[-12,0]}$ & $\begin{array}{c}0.130 * * * \\
(0.000)\end{array}$ & $\begin{array}{c}0.130 * * * \\
(0.000)\end{array}$ \\
\hline$R O A$ & $\begin{array}{c}0.378 * * * \\
(0.003)\end{array}$ & $\begin{array}{c}0.377 * * * \\
(0.003)\end{array}$ \\
\hline M/B Ratio & $\begin{array}{c}0.022 * * * \\
(0.000)\end{array}$ & $\begin{array}{c}0.022 * * * \\
(0.000)\end{array}$ \\
\hline Cash/Assets & $\begin{array}{c}0.026 \\
(0.835)\end{array}$ & $\begin{array}{c}0.032 \\
(0.802)\end{array}$ \\
\hline Leverage & $\begin{array}{c}-0.277 * * * \\
(0.000)\end{array}$ & $\begin{array}{c}-0.274 * * * \\
(0.000)\end{array}$ \\
\hline Capex/Assets & $\begin{array}{c}0.432 \\
(0.139)\end{array}$ & $\begin{array}{c}0.448 \\
(0.122)\end{array}$ \\
\hline CEO characteristics & & \\
\hline CEO Age & $\begin{array}{l}-0.002 \\
(0.288)\end{array}$ & $\begin{array}{l}-0.001 \\
(0.305)\end{array}$ \\
\hline CEO Ownership & $\begin{array}{c}-0.005^{*} \\
(0.068)\end{array}$ & $\begin{array}{c}-0.005^{*} \\
(0.069)\end{array}$ \\
\hline Intercept & Yes & Yes \\
\hline Year Fixed Effects & Yes & Yes \\
\hline Firm Fixed Effects & Yes & Yes \\
\hline Clustered by firm and year & Yes & Yes \\
\hline Obs & 10,792 & 10,792 \\
\hline Adj. $R^{2}$ & 0.7060 & 0.7066 \\
\hline
\end{tabular}


Table 4. Effect of terrorist attacks on CEO compensation: Robustness tests

This table presents coefficients from difference-in-difference (DiD) regressions of the effect of terrorist attacks on executive compensation using an alternative measure of executive compensation (Panel A), alternative measures of attack proximity (Panel B), and distance to the attacks as the dependent variable (Panel C). The treatment and control groups are defined as in Table 2. All variables are defined in Appendix B. $P$-values clustered by firm and year are in parentheses. * $* *$, and *** represent significance at the $10 \%$, $5 \%$, and $1 \%$ levels, respectively.

Panel A: Alternative measure of executive compensation

\begin{tabular}{|c|c|c|c|}
\hline \multirow[b]{2}{*}{ VARIABLES } & \multicolumn{3}{|c|}{$\operatorname{Ln}(\text { Ex Post Pay })_{t+1}$} \\
\hline & $(1)$ & $(2)$ & (3) \\
\hline Attack Proximity & $\begin{array}{c}0.127 * * * \\
(0.000)\end{array}$ & $\begin{array}{c}0.139 * * * \\
(0.000)\end{array}$ & $\begin{array}{c}0.138 * * * \\
(0.000)\end{array}$ \\
\hline Firm characteristics & & & \\
\hline Firm size & & $\begin{array}{c}0.218^{* * *} \\
(0.000)\end{array}$ & $\begin{array}{c}0.212 * * * \\
(0.000)\end{array}$ \\
\hline Volatility & & $\begin{array}{c}-1.059^{* *} \\
(0.010)\end{array}$ & $\begin{array}{c}-1.013 * * \\
(0.013)\end{array}$ \\
\hline$R E T_{[-12,0]}$ & & $\begin{array}{c}0.262 * * * \\
(0.000)\end{array}$ & $\begin{array}{c}0.263 * * * \\
(0.000)\end{array}$ \\
\hline$R O A$ & & $\begin{array}{c}0.809 * * * \\
(0.000)\end{array}$ & $\begin{array}{c}0.812^{* * *} * \\
(0.000)\end{array}$ \\
\hline M/B Ratio & & $\begin{array}{c}0.033 * * * \\
(0.000)\end{array}$ & $\begin{array}{c}0.033^{* * *} * \\
(0.000)\end{array}$ \\
\hline Cash/Assets & & $\begin{array}{l}-0.050 \\
(0.690)\end{array}$ & $\begin{array}{l}-0.052 \\
(0.680)\end{array}$ \\
\hline Leverage & & $\begin{array}{c}-0.236^{* * * *} \\
(0.000)\end{array}$ & $\begin{array}{c}-0.232 * * * \\
(0.000)\end{array}$ \\
\hline Capex/Assets & & $\begin{array}{c}0.418 \\
(0.187)\end{array}$ & $\begin{array}{c}0.427 \\
(0.181)\end{array}$ \\
\hline CEO characteristics & & & \\
\hline CEO Age & & & $\begin{array}{c}0.002 \\
(0.153)\end{array}$ \\
\hline CEO Ownership & & & $\begin{array}{c}-0.008^{* *} \\
(0.011)\end{array}$ \\
\hline Intercept & Yes & Yes & Yes \\
\hline Year Fixed Effects & Yes & Yes & Yes \\
\hline Firm Fixed Effects & Yes & Yes & Yes \\
\hline Clustered by firm and year & Yes & Yes & Yes \\
\hline Obs & 22,561 & 22,561 & 22,561 \\
\hline Adj. $R^{2}$ & 0.592 & 0.617 & 0.617 \\
\hline
\end{tabular}


Panel B: Alternative measures of attack proximity

\begin{tabular}{|c|c|c|c|c|}
\hline Cutoff distance $=$ & 30 miles & 50 miles & 200 miles & $\begin{array}{c}(4) \\
\text { First attack } \\
\text { within } 100 \\
\text { miles }\end{array}$ \\
\hline Attack Proximity & $\begin{array}{c}0.110 * * * \\
(0.000)\end{array}$ & $\begin{array}{c}0.108 * * * \\
(0.000)\end{array}$ & $\begin{array}{c}0.097 * * * \\
(0.000)\end{array}$ & $\begin{array}{c}0.103 * * \\
(0.014)\end{array}$ \\
\hline \multicolumn{5}{|l|}{ Firm characteristics } \\
\hline Firm size & $\begin{array}{c}0.254 * * * \\
(0.000)\end{array}$ & $\begin{array}{c}0.250^{* * *} \\
(0.000)\end{array}$ & $\begin{array}{c}0.234 * * * \\
(0.000)\end{array}$ & $\begin{array}{c}0.243^{* * *} * \\
(0.000)\end{array}$ \\
\hline Volatility & $\begin{array}{c}0.109 \\
(0.700)\end{array}$ & $\begin{array}{c}0.171 \\
(0.553)\end{array}$ & $\begin{array}{c}0.141 \\
(0.628)\end{array}$ & $\begin{array}{c}0.055 \\
(0.844)\end{array}$ \\
\hline$R E T_{[-12,0]}$ & $\begin{array}{c}0.144 * * * \\
(0.000)\end{array}$ & $\begin{array}{c}0.149 * * * \\
(0.000)\end{array}$ & $\begin{array}{c}0.149 * * * \\
(0.000)\end{array}$ & $\begin{array}{c}0.144^{* * *} * \\
(0.000)\end{array}$ \\
\hline$R O A$ & $\begin{array}{c}0.484 * * * \\
(0.000)\end{array}$ & $\begin{array}{c}0.481^{* * *} \\
(0.000)\end{array}$ & $\begin{array}{c}0.449 * * * \\
(0.000)\end{array}$ & $\begin{array}{c}0.427 * * * \\
(0.000)\end{array}$ \\
\hline M/B Ratio & $\begin{array}{c}0.022 * * * \\
(0.000)\end{array}$ & $\begin{array}{c}0.020 * * * \\
(0.000)\end{array}$ & $\begin{array}{c}0.019 * * * \\
(0.000)\end{array}$ & $\begin{array}{c}0.022 * * * \\
(0.000)\end{array}$ \\
\hline Cash/Assets & $\begin{array}{l}-0.024 \\
(0.769)\end{array}$ & $\begin{array}{l}-0.040 \\
(0.622)\end{array}$ & $\begin{array}{l}-0.072 \\
(0.404)\end{array}$ & $\begin{array}{l}-0.046 \\
(0.517)\end{array}$ \\
\hline Leverage & $\begin{array}{c}-0.217 * * * \\
(0.000)\end{array}$ & $\begin{array}{c}-0.233^{* * *} \\
(0.000)\end{array}$ & $\begin{array}{c}-0.242 * * * \\
(0.000)\end{array}$ & $\begin{array}{c}-0.226^{* * *} \\
(0.000)\end{array}$ \\
\hline Capex/Assets & $\begin{array}{c}0.245 \\
(0.241)\end{array}$ & $\begin{array}{c}0.209 \\
(0.320)\end{array}$ & $\begin{array}{c}0.322 \\
(0.132)\end{array}$ & $\begin{array}{c}0.248 \\
(0.243)\end{array}$ \\
\hline CEO characteristics & & & & \\
\hline CEO Age & $\begin{array}{l}-0.001 \\
(0.202)\end{array}$ & $\begin{array}{c}-0.002 \\
(0.151)\end{array}$ & $\begin{array}{l}-0.001 \\
(0.511)\end{array}$ & $\begin{array}{l}-0.001 \\
(0.360)\end{array}$ \\
\hline CEO Ownership & $\begin{array}{c}-0.006^{* *} \\
(0.016)\end{array}$ & $\begin{array}{c}-0.005^{* *} \\
(0.034)\end{array}$ & $\begin{array}{c}-0.005^{* *} \\
(0.049)\end{array}$ & $\begin{array}{c}-0.006^{* *} \\
(0.017)\end{array}$ \\
\hline Intercept & Yes & Yes & Yes & Yes \\
\hline Year Fixed Effects & Yes & Yes & Yes & Yes \\
\hline Firm Fixed Effects & Yes & Yes & Yes & Yes \\
\hline Clustered by firm and year & Yes & Yes & Yes & Yes \\
\hline Obs & 20,590 & 21,354 & 19,222 & 22,561 \\
\hline Adj. $R^{2}$ & 0.7234 & 0.7222 & 0.7265 & 0.7242 \\
\hline
\end{tabular}


Panel C: Using distance to the attacks as the attack variable

\begin{tabular}{|c|c|c|c|}
\hline & (1) & (2) & (3) \\
\hline Ln(Distance) & $\begin{array}{c}-0.015^{* *} \\
(0.024)\end{array}$ & $\begin{array}{c}-0.015^{* * *} \\
(0.009)\end{array}$ & $\begin{array}{c}-0.015 * * * \\
(0.009)\end{array}$ \\
\hline \multicolumn{4}{|l|}{ Firm characteristics } \\
\hline Firm size & & $\begin{array}{c}0.279 * * * \\
(0.000)\end{array}$ & $\begin{array}{c}0.278 * * * \\
(0.000)\end{array}$ \\
\hline Volatility & & $\begin{array}{c}0.247 \\
(0.527)\end{array}$ & $\begin{array}{c}0.275 \\
(0.482)\end{array}$ \\
\hline$R E T_{[-12,0]}$ & & $\begin{array}{c}0.149 * * * \\
(0.000)\end{array}$ & $\begin{array}{c}0.149 * * * \\
(0.000)\end{array}$ \\
\hline$R O A$ & & $\begin{array}{c}0.419 * * * \\
(0.003)\end{array}$ & $\begin{array}{c}0.421 * * * \\
(0.003)\end{array}$ \\
\hline M/B Ratio & & $\begin{array}{c}0.026 * * * \\
(0.001)\end{array}$ & $\begin{array}{c}0.027 * * * \\
(0.000)\end{array}$ \\
\hline Cash/Assets & & $\begin{array}{c}0.038 \\
(0.774)\end{array}$ & $\begin{array}{c}0.035 \\
(0.788)\end{array}$ \\
\hline Leverage & & $\begin{array}{c}-0.291 * * * \\
(0.000)\end{array}$ & $\begin{array}{c}-0.291 * * * \\
(0.000)\end{array}$ \\
\hline Capex/Assets & & $\begin{array}{c}0.417 \\
(0.180)\end{array}$ & $\begin{array}{c}0.432 \\
(0.165)\end{array}$ \\
\hline CEO characteristics & & & \\
\hline CEO Age & & & $\begin{array}{l}-0.001 \\
(0.448)\end{array}$ \\
\hline CEO Ownership & & & $\begin{array}{l}-0.006^{*} \\
(0.068)\end{array}$ \\
\hline Intercept & Yes & Yes & Yes \\
\hline Year Fixed Effects & Yes & Yes & Yes \\
\hline Firm Fixed Effects & Yes & Yes & Yes \\
\hline Clustered by firm and year & Yes & Yes & Yes \\
\hline Obs & 10,584 & 10,584 & 10,584 \\
\hline Adj. $R^{2}$ & 0.6915 & 0.7103 & 0.7106 \\
\hline
\end{tabular}


Table 5. Two-way attack proximity coefficient matrix for varying distances and periods around the attacks

This table presents coefficients from difference-in-difference (DiD) regressions (Table 2 Model 3) of the effect of terrorist attacks on executive compensation. The dependent variable is $\operatorname{Ln}$ (Total Pay) measured over different years from one year before to three years after the attack. The treatment group includes all firms that are affected by the attacks that have occurred at time $t$, specifically, firms that are headquartered within the specified number of miles of the location of the terrorist events and at least three years have elapsed since the last attack. The control group includes the treatment firms before time $t$ and all remaining firms. In each case, we control for firm and CEO characteristics and firm and year fixed effects. $P$-values clustered by firm and year are in parentheses. Significant variables are bolded. *,**, and *** represent significance at the $10 \%, 5 \%$, and $1 \%$ levels, respectively.

\begin{tabular}{|c|c|c|c|c|c|}
\hline Dependent variable & $\operatorname{Ln}($ Total Pay $) \mathrm{t}-1$ & Ln $($ Total Pay $) \mathrm{t}$ & $\operatorname{Ln}($ Total Pay $) \mathrm{t}+1$ & $\operatorname{Ln}(\text { Total Pay })_{\mathrm{t}+2}$ & Ln(Total Pay $) \mathrm{t}+3$ \\
\hline \multirow[t]{2}{*}{ Attack proximity (within 30 miles) } & 0.003 & 0.003 & $0.110 * * *$ & $0.044 *$ & -0.020 \\
\hline & $(0.903)$ & $(0.914)$ & $(0.000)$ & $(0.082)$ & $(0.413)$ \\
\hline \multirow[t]{2}{*}{ Attack proximity (within 50 miles) } & -0.003 & -0.007 & $0.108 * * *$ & $0.054 *$ & -0.010 \\
\hline & $(0.882)$ & $(0.670)$ & (0.000) & $(0.063)$ & $(0.670)$ \\
\hline \multirow[t]{2}{*}{ Attack proximity (within 100 miles) } & 0.002 & -0.012 & $0.109 * * *$ & $0.052 *$ & -0.035 \\
\hline & $(0.891)$ & $(0.392)$ & $(0.000)$ & $(0.072)$ & $(0.181)$ \\
\hline \multirow[t]{2}{*}{ Attack proximity (within 150 miles) } & 0.000 & -0.009 & $0.084 * * *$ & $0.040 *$ & -0.014 \\
\hline & $(0.985)$ & $(0.574)$ & $(0.000)$ & $(0.077)$ & $(0.507)$ \\
\hline \multirow{2}{*}{ Attack proximity (within 200 miles) } & 0.013 & -0.003 & $0.097 * * *$ & 0.031 & -0.032 \\
\hline & $(0.476)$ & $(0.852)$ & $(0.000)$ & $(0.255)$ & $(0.206)$ \\
\hline \multirow[t]{2}{*}{ Attack proximity (within 250 miles) } & 0.000 & -0.009 & $0.048 * * *$ & 0.018 & -0.022 \\
\hline & $(0.985)$ & $(0.574)$ & $(0.005)$ & $(0.364)$ & $(0.261)$ \\
\hline \multirow[t]{2}{*}{ Attack proximity (within 300 miles) } & 0.039 & 0.021 & 0.001 & -0.018 & -0.038 \\
\hline & $(0.144)$ & $(0.342)$ & $(0.959)$ & $(0.507)$ & $(0.258)$ \\
\hline \multirow[t]{2}{*}{ Attack proximity (within 400 miles) } & 0.036 & 0.024 & 0.014 & -0.015 & -0.029 \\
\hline & $(0.191)$ & $(0.343)$ & $(0.643)$ & $(0.642)$ & $(0.457)$ \\
\hline
\end{tabular}




\section{Table 6. Effect of terrorist attacks on the composition of CEO compensation}

This table presents coefficients from a difference-in-difference (DiD) regression of the effect of terrorist attacks on the composition of executive compensation. The dependent variable Attack Proximity is defined as in Table 2. All variables are defined in Appendix B. P-values clustered by firm and year are in parentheses. $* * *$, and $* * *$ represent significance at the $10 \%, 5 \%$, and $1 \%$ levels, respectively.

\begin{tabular}{|c|c|c|c|c|c|c|c|c|}
\hline Dependent variable & $\operatorname{Ln}(\text { Salary })_{t+1}$ & Ln(Bonus $)_{t+1}$ & $\begin{array}{c}(3) \\
\text { Ln(Cash- } \\
\text { based Pay })_{t+1}\end{array}$ & $\begin{array}{c}\text { (4) } \\
\text { Ln(Option } \\
{\text { Value })_{t+1}}\end{array}$ & $\begin{array}{c}\text { (5) } \\
\text { Ln(Stock } \\
{\text { Value })_{t+1}}\end{array}$ & $\begin{array}{c}\text { (6) } \\
\text { Ln(LTIP } \\
{\text { Value })_{t+1}}\end{array}$ & $\begin{array}{c}\text { (7) } \\
\text { Ln(Equity- } \\
\text { based Pay) }{ }_{t+1}\end{array}$ & $\begin{array}{c}\text { (8) } \\
\text { Cash to total } \\
\text { Compensation } \\
\text { Ratio }_{t+1} \\
\end{array}$ \\
\hline Attack Proximity & $\begin{array}{c}0.135^{* * * *} \\
(0.000)\end{array}$ & $\begin{array}{c}0.197 * * \\
(0.021)\end{array}$ & $\begin{array}{c}0.179 * * * \\
(0.000)\end{array}$ & $\begin{array}{l}-0.109 \\
(0.242)\end{array}$ & $\begin{array}{l}-0.084 \\
(0.316)\end{array}$ & $\begin{array}{c}0.018 \\
(0.787)\end{array}$ & $\begin{array}{l}-0.080 \\
(0.342)\end{array}$ & $\begin{array}{c}0.017 * * * \\
(0.000)\end{array}$ \\
\hline Firm characteristics & & & & & & & & \\
\hline Firm size & $\begin{array}{c}0.119 * * * \\
(0.000)\end{array}$ & $\begin{array}{c}-0.324^{* * *} \\
(0.002)\end{array}$ & $\begin{array}{c}0.070^{* * * *} \\
(0.002)\end{array}$ & $\begin{array}{c}0.089 \\
(0.255)\end{array}$ & $\begin{array}{l}-0.019 \\
(0.759)\end{array}$ & $\begin{array}{c}0.066 \\
(0.296)\end{array}$ & $\begin{array}{c}0.084 \\
(0.211)\end{array}$ & $\begin{array}{c}-0.018 * * * \\
(0.000)\end{array}$ \\
\hline Volatility & $\begin{array}{c}0.072 \\
(0.758)\end{array}$ & $\begin{array}{l}-1.581 \\
(0.147)\end{array}$ & $\begin{array}{l}-0.215 \\
(0.363)\end{array}$ & $\begin{array}{c}2.117 * * * \\
(0.008)\end{array}$ & $\begin{array}{c}-3.421 * * * \\
(0.001)\end{array}$ & $\begin{array}{c}-3.737 * * * \\
(0.000)\end{array}$ & $\begin{array}{c}0.619 \\
(0.372)\end{array}$ & $\begin{array}{l}-0.009 \\
(0.812)\end{array}$ \\
\hline$R E T_{[-12,0]}$ & $\begin{array}{c}0.031 * * \\
(0.016)\end{array}$ & $\begin{array}{c}0.366 * * * \\
(0.000)\end{array}$ & $\begin{array}{c}0.080 * * * \\
(0.000)\end{array}$ & $\begin{array}{c}0.072 \\
(0.279)\end{array}$ & $\begin{array}{c}0.070 \\
(0.202)\end{array}$ & $\begin{array}{c}0.121 * * \\
(0.031)\end{array}$ & $\begin{array}{l}0.096^{*} \\
(0.070)\end{array}$ & $\begin{array}{c}-0.013 * * * \\
(0.000)\end{array}$ \\
\hline$R O A$ & $\begin{array}{c}0.346^{* * * *} \\
(0.001)\end{array}$ & $\begin{array}{l}-0.185 \\
(0.727)\end{array}$ & $\begin{array}{c}0.313 * * * \\
(0.004)\end{array}$ & $\begin{array}{c}-0.151 \\
(0.582)\end{array}$ & $\begin{array}{c}0.038 \\
(0.907)\end{array}$ & $\begin{array}{l}-0.102 \\
(0.590)\end{array}$ & $\begin{array}{l}-0.071 \\
(0.789)\end{array}$ & $\begin{array}{c}-0.023^{*} \\
(0.096)\end{array}$ \\
\hline M/B Ratio & $\begin{array}{c}-0.002 \\
(0.565)\end{array}$ & $\begin{array}{l}-0.010 \\
(0.383)\end{array}$ & $\begin{array}{l}-0.001 \\
(0.780)\end{array}$ & $\begin{array}{c}0.044 * * \\
(0.031)\end{array}$ & $\begin{array}{c}-0.030 * * \\
(0.024)\end{array}$ & $\begin{array}{l}-0.003 \\
(0.788)\end{array}$ & $\begin{array}{c}0.037 * * \\
(0.027)\end{array}$ & $\begin{array}{c}-0.003 * * * \\
(0.005)\end{array}$ \\
\hline Cash/Assets & $\begin{array}{l}-0.141 \\
(0.310)\end{array}$ & $\begin{array}{l}-0.490^{*} \\
(0.095)\end{array}$ & $\begin{array}{l}-0.220^{*} \\
(0.070)\end{array}$ & $\begin{array}{l}-0.424 \\
(0.238)\end{array}$ & $\begin{array}{c}-0.526^{* *} \\
(0.044)\end{array}$ & $\begin{array}{c}-0.639 * * * \\
(0.002)\end{array}$ & $\begin{array}{c}-0.651 * * \\
(0.022)\end{array}$ & $\begin{array}{l}-0.015 \\
(0.308)\end{array}$ \\
\hline Leverage & $\begin{array}{l}-0.025 \\
(0.499)\end{array}$ & $\begin{array}{c}-0.291 * * \\
(0.029)\end{array}$ & $\begin{array}{c}-0.081 * * \\
(0.029)\end{array}$ & $\begin{array}{c}-0.605^{* * *} \\
(0.000)\end{array}$ & $\begin{array}{l}-0.020 \\
(0.877)\end{array}$ & $\begin{array}{l}-0.069 \\
(0.512)\end{array}$ & $\begin{array}{c}-0.493 * * * \\
(0.001)\end{array}$ & $\begin{array}{c}0.014 * * \\
(0.026)\end{array}$ \\
\hline Capex/Assets & $\begin{array}{c}0.120 \\
(0.537)\end{array}$ & $\begin{array}{l}-2.307^{*} \\
(0.086)\end{array}$ & $\begin{array}{l}-0.171 \\
(0.460)\end{array}$ & $\begin{array}{l}1.745^{*} \\
(0.087)\end{array}$ & $\begin{array}{c}-1.751 * * * \\
(0.009)\end{array}$ & $\begin{array}{c}-1.719 * * * \\
(0.007)\end{array}$ & $\begin{array}{c}0.473 \\
(0.462)\end{array}$ & $\begin{array}{l}-0.015 \\
(0.596)\end{array}$ \\
\hline CEO characteristics & & & & & & & & \\
\hline CEO Age & $\begin{array}{c}0.000 \\
(0.952)\end{array}$ & $\begin{array}{l}0.010^{*} \\
(0.063)\end{array}$ & $\begin{array}{c}0.001 \\
(0.516)\end{array}$ & $\begin{array}{c}-0.012 * * \\
(0.043)\end{array}$ & $\begin{array}{l}-0.004 \\
(0.318)\end{array}$ & $\begin{array}{c}0.004 \\
(0.236)\end{array}$ & $\begin{array}{l}-0.008^{*} \\
(0.071)\end{array}$ & $\begin{array}{c}0.000 \\
(0.981)\end{array}$ \\
\hline CEO Ownership & $\begin{array}{c}-0.008^{* *} \\
(0.011)\end{array}$ & $\begin{array}{c}-0.018 * * \\
(0.027)\end{array}$ & $\begin{array}{c}-0.008 * * * \\
(0.006)\end{array}$ & $\begin{array}{c}-0.043^{* * *} \\
(0.001)\end{array}$ & $\begin{array}{c}-0.019^{* * *} \\
(0.003)\end{array}$ & $\begin{array}{c}-0.017 * * * \\
(0.001)\end{array}$ & $\begin{array}{c}-0.044 * * * \\
(0.000)\end{array}$ & $\begin{array}{c}0.000 \\
(0.236)\end{array}$ \\
\hline $\begin{array}{l}\text { Lagged Pay } \\
\text { Ln(Total Pay) }\end{array}$ & & & & & & & & $\begin{array}{c}-0.016 * * * \\
(0.000)\end{array}$ \\
\hline
\end{tabular}




\begin{tabular}{|c|c|c|c|c|c|c|c|c|}
\hline Intercept & Yes & Yes & Yes & Yes & Yes & Yes & Yes & Yes \\
\hline Year Fixed Effects & Yes & Yes & Yes & Yes & Yes & Yes & Yes & Yes \\
\hline $\begin{array}{l}\text { Firm Fixed Effects } \\
\text { Clustered by firm and }\end{array}$ & Yes & Yes & Yes & Yes & Yes & Yes & Yes & Yes \\
\hline year & Yes & Yes & Yes & Yes & Yes & Yes & Yes & Yes \\
\hline Obs & 22,561 & 22,561 & 22,561 & 22,561 & 22,561 & 22,561 & 22,561 & 20,230 \\
\hline Adj. $R^{2}$ & 0.521 & 0.557 & 0.583 & 0.651 & 0.350 & 0.388 & 0.720 & 0.465 \\
\hline
\end{tabular}


Table 7. Do company policies change in response to terrorist attacks?

This table presents difference-in-differences (DiD) estimates of the effect of the proximity of a terrorist attack on the level of firm policy variables in the year after the attack (Panel A) and at different quarters surrounding the attack (Panel B). The variable Cash is defined as Cash items scaled by total assets (CHEQ/ATQ); Leverage is defined as the sum of current liabilities and long-term debt divided by total assets ((DLCQ+DLTTQ)/ATQ); $N W C$ is defined as Net working capital (Inventories + receivables - payables scaled by total revenues) ((INVTQ+RECTQ-APQ)/REVTQ); R\&D is defined as R\&D expenses over total assets (XRDQ/ATQ); Investment is defined as Total cash flow from investing activities (capital expenditures + acquisition expenditures) scaled by net property, plant, and equipment ((CAPXQ+AQCY)/PPENTQ); AP is defined as Payables scaled by total revenues (APQ/REVTQ); Receivables is defined as Receivables scaled by total revenues (RECTQ/REVTQ). $q+i$ is a dummy variable equal to 1 if the county of the firm headquarters at quarter $q+i$ is in the area affected by an attack during quarter $q_{0}$. All other variables are defined in Appendix B. $P$-values clustered by firm and year-quarter are in parentheses. *, **, and *** represent significance at the $10 \%, 5 \%$, and $1 \%$ levels, respectively.

Panel A: Impact of attack proximity on firm policy variables following the attack

\begin{tabular}{lccccccc}
\hline & $(1)$ & $(2)$ & $(3)$ & $(4)$ & $(5)$ & $(6)$ & $(7)$ \\
Dependent variable & Cash $_{t+1}$ & Leverage $_{t+1}$ & $N W C_{t+1}$ & $R \& D_{t+1}$ & Investment $_{t+1}$ & $A P_{t+1}$ & Receivables $_{t+1}$ \\
\hline Attack Proximity & -0.004 & -0.001 & -0.002 & -0.000 & 0.002 & $-0.024^{*}$ & $-0.029^{*}$ \\
& $(0.127)$ & $(0.664)$ & $(0.871)$ & $(0.885)$ & $(0.867)$ & $(0.070)$ & $(0.065)$ \\
Intercept & Yes & Yes & Yes & Yes & Yes & Yes & Yes \\
Year-quarter Fixed Effects & Yes & Yes & Yes & Yes & Yes & Yes & Yes \\
Firm Fixed Effects & Yes & Yes & Yes & Yes & Yes & Yes & Yes \\
Clustered by firm and year-quarter & Yes & Yes & Yes & Yes & Yes & Yes & Yes \\
Obs & 68,576 & 64,675 & 64,006 & 68,576 & 66,049 & 64,006 & 64,006 \\
Adj. $R^{2}$ & 0.7900 & 0.7476 & 0.8228 & 0.8203 & 0.3364 & 0.7969 & 0.8740 \\
\hline
\end{tabular}


Panel B: Impact of attack proximity on firm policy variables over time

\begin{tabular}{|c|c|c|c|c|c|c|c|}
\hline Dependent variable & $\begin{array}{c}(1) \\
\text { Cash }_{t+1}\end{array}$ & $\begin{array}{c}\text { (2) } \\
\text { Leverage }_{t+1}\end{array}$ & $\begin{array}{c}(3) \\
N W C_{t+1}\end{array}$ & $\begin{array}{c}(4) \\
R \& D_{t+1}\end{array}$ & $\begin{array}{c}(5) \\
\text { Investment }_{t+1}\end{array}$ & $\begin{array}{c}(6) \\
A P_{t+1}\end{array}$ & $\begin{array}{c}(7) \\
\text { Receivables }_{t+1}\end{array}$ \\
\hline$q-4$ & $\begin{array}{c}0.001 \\
(0.714)\end{array}$ & $\begin{array}{c}-0.004 * * \\
(0.025)\end{array}$ & $\begin{array}{l}-0.004 \\
(0.850)\end{array}$ & $\begin{array}{l}-0.000 \\
(0.661)\end{array}$ & $\begin{array}{l}-0.007 \\
(0.655)\end{array}$ & $\begin{array}{c}0.004 \\
(0.679)\end{array}$ & $\begin{array}{c}0.003 \\
(0.798)\end{array}$ \\
\hline$q-3$ & $\begin{array}{c}0.003 \\
(0.189)\end{array}$ & $\begin{array}{l}-0.004 \\
(0.218)\end{array}$ & $\begin{array}{l}-0.019 \\
(0.305)\end{array}$ & $\begin{array}{l}-0.000 \\
(0.199)\end{array}$ & $\begin{array}{l}-0.010 \\
(0.586)\end{array}$ & $\begin{array}{l}-0.003 \\
(0.747)\end{array}$ & $\begin{array}{l}-0.011 \\
(0.176)\end{array}$ \\
\hline$q-2$ & $\begin{array}{c}0.003 \\
(0.260)\end{array}$ & $\begin{array}{l}-0.004 \\
(0.197)\end{array}$ & $\begin{array}{l}-0.023 \\
(0.102)\end{array}$ & $\begin{array}{l}-0.000 \\
(0.452)\end{array}$ & $\begin{array}{l}-0.003 \\
(0.886)\end{array}$ & $\begin{array}{l}-0.006 \\
(0.465)\end{array}$ & $\begin{array}{c}-0.022 * * \\
(0.014)\end{array}$ \\
\hline$q-1$ & $\begin{array}{l}0.001 \\
(0.709)\end{array}$ & $\begin{array}{c}-0.006 * * \\
(0.032)\end{array}$ & $\begin{array}{c}-0.031 * * \\
(0.049)\end{array}$ & $\begin{array}{l}0.000 \\
(0.857)\end{array}$ & $\begin{array}{l}-0.012 \\
(0.520)\end{array}$ & $\begin{array}{l}-0.005 \\
(0.644)\end{array}$ & $\begin{array}{l}-0.012 \\
(0.277)\end{array}$ \\
\hline$q 0$ & $\begin{array}{c}0.002 \\
(0.612)\end{array}$ & $\begin{array}{c}-0.006^{* *} \\
(0.047)\end{array}$ & $\begin{array}{c}-0.028^{*} \\
(0.098)\end{array}$ & $\begin{array}{l}-0.000 \\
(0.428)\end{array}$ & $\begin{array}{l}-0.013 \\
(0.476)\end{array}$ & $\begin{array}{l}-0.017 \\
(0.293)\end{array}$ & $\begin{array}{c}-0.031 * * \\
(0.028)\end{array}$ \\
\hline$q+1$ & $\begin{array}{c}0.001 \\
(0.644)\end{array}$ & $\begin{array}{l}-0.005 \\
(0.157)\end{array}$ & $\begin{array}{l}-0.031 \\
(0.108)\end{array}$ & $\begin{array}{l}-0.001 * \\
(0.087)\end{array}$ & $\begin{array}{l}-0.023 \\
(0.151)\end{array}$ & $\begin{array}{l}-0.029 \\
(0.130)\end{array}$ & $\begin{array}{c}-0.043 * * \\
(0.016)\end{array}$ \\
\hline$q+2$ & $\begin{array}{l}-0.001 \\
(0.861)\end{array}$ & $\begin{array}{l}-0.007^{*} \\
(0.065)\end{array}$ & $\begin{array}{l}-0.013 \\
(0.489)\end{array}$ & $\begin{array}{l}-0.000 \\
(0.652)\end{array}$ & $\begin{array}{l}-0.012 \\
(0.416)\end{array}$ & $\begin{array}{l}-0.017 \\
(0.277)\end{array}$ & $\begin{array}{c}-0.038 * * \\
(0.025)\end{array}$ \\
\hline$q+3$ & $\begin{array}{l}-0.003 \\
(0.418)\end{array}$ & $\begin{array}{l}-0.007 \\
(0.111)\end{array}$ & $\begin{array}{c}0.005 \\
(0.770)\end{array}$ & $\begin{array}{l}-0.000 \\
(0.904)\end{array}$ & $\begin{array}{c}0.004 \\
(0.828)\end{array}$ & $\begin{array}{l}-0.037^{*} \\
(0.052)\end{array}$ & $\begin{array}{l}-0.032^{*} \\
(0.100)\end{array}$ \\
\hline$q+4$ & $\begin{array}{l}-0.003 \\
(0.482)\end{array}$ & $\begin{array}{l}-0.003 \\
(0.417)\end{array}$ & $\begin{array}{l}-0.010 \\
(0.606)\end{array}$ & $\begin{array}{l}-0.000 \\
(0.842)\end{array}$ & $\begin{array}{c}0.007 \\
(0.687)\end{array}$ & $\begin{array}{l}-0.026 \\
(0.202)\end{array}$ & $\begin{array}{c}-0.042 * * \\
(0.029)\end{array}$ \\
\hline$q+5$ & $\begin{array}{l}-0.005 \\
(0.141)\end{array}$ & $\begin{array}{l}-0.001 \\
(0.843)\end{array}$ & $\begin{array}{l}-0.001 \\
(0.963)\end{array}$ & $\begin{array}{l}-0.000 \\
(0.466)\end{array}$ & $\begin{array}{c}0.001 \\
(0.966)\end{array}$ & $\begin{array}{l}-0.035^{*} \\
(0.069)\end{array}$ & $\begin{array}{l}-0.039^{*} \\
(0.073)\end{array}$ \\
\hline$q+6$ & $\begin{array}{l}-0.006^{*} \\
(0.088)\end{array}$ & $\begin{array}{l}-0.002 \\
(0.611)\end{array}$ & $\begin{array}{l}-0.013 \\
(0.544)\end{array}$ & $\begin{array}{c}0.000 \\
(0.744)\end{array}$ & $\begin{array}{c}0.004 \\
(0.863)\end{array}$ & $\begin{array}{l}-0.020 \\
(0.216)\end{array}$ & $\begin{array}{l}-0.030 \\
(0.171)\end{array}$ \\
\hline$q+7$ & $\begin{array}{l}-0.007^{*} \\
(0.082)\end{array}$ & $\begin{array}{l}-0.000 \\
(0.912)\end{array}$ & $\begin{array}{l}-0.017 \\
(0.382)\end{array}$ & $\begin{array}{c}0.000 \\
(0.374)\end{array}$ & $\begin{array}{c}0.010 \\
(0.677)\end{array}$ & $\begin{array}{l}-0.027 * \\
(0.084)\end{array}$ & $\begin{array}{l}-0.035 \\
(0.149)\end{array}$ \\
\hline$q+8$ & $\begin{array}{l}-0.004 \\
(0.222)\end{array}$ & $\begin{array}{l}-0.001 \\
(0.855)\end{array}$ & $\begin{array}{c}0.005 \\
(0.832)\end{array}$ & $\begin{array}{l}-0.000 \\
(0.416)\end{array}$ & $\begin{array}{c}0.005 \\
(0.760)\end{array}$ & $\begin{array}{l}-0.022 \\
(0.145)\end{array}$ & $\begin{array}{l}-0.020 \\
(0.405)\end{array}$ \\
\hline Intercept & Yes & Yes & Yes & Yes & Yes & Yes & Yes \\
\hline Year-quarter Fixed Effects & Yes & Yes & Yes & Yes & Yes & Yes & Yes \\
\hline Firm Fixed Effects & Yes & Yes & Yes & Yes & Yes & Yes & Yes \\
\hline Clustered by firm and year-quarter & Yes & Yes & Yes & Yes & Yes & Yes & Yes \\
\hline Obs & 68,576 & 64,675 & 64,006 & 68,576 & 66,049 & 64,006 & 64,006 \\
\hline Adj. $R^{2}$ & 0.790 & 0.748 & 0.823 & 0.820 & 0.336 & 0.797 & 0.874 \\
\hline
\end{tabular}




\section{Table 8. Effects on shareholders}

This table reports post-attack long term cumulative abnormal returns of the firms affected by the terrorist attack. Affected firms are defined as in Table 2. Cumulative abnormal returns (CARs) are defined as the stock returns of the treatment firm minus that of its control firm. We use the PSM method for one-to-one matching as in Table 3 to obtain 769 matched pairs (some events may affect more than one firm). *, **, and $* * *$ represent significance at the $10 \%, 5 \%$, and $1 \%$ levels, respectively.

\begin{tabular}{rcccc}
\hline & \multicolumn{3}{c}{ CARs } \\
\cline { 2 - 5 } Period & Mean & Median & $p$-value for $t$-test & $\begin{array}{c}p \text {-value for } \\
\text { Wilcoxon signed- } \\
\text { rank test }\end{array}$ \\
\hline 6 months & $-0.040^{* *}$ & $-0.022^{*}$ & 0.015 & 0.057 \\
8 months & $-0.062^{* * *}$ & $-0.021^{* *}$ & 0.003 & 0.014 \\
10 months & $-0.078^{* * *}$ & $-0.022^{* *}$ & 0.002 & 0.016 \\
12 months & $-0.092^{* * *}$ & $-0.028^{* *}$ & 0.002 & 0.024 \\
\hline
\end{tabular}


Table 9. Does CEO bargaining power influence the effect of terrorist attacks on pay?

This table presents coefficients from difference-in-difference (DiD) regressions where attack proximity is defined as in Table 2. All variables are defined in Appendix B. $P$-values clustered by firm and year are in parentheses. $* * *$, and $* * *$ represent significance at the $10 \%, 5 \%$, and $1 \%$ levels, respectively.

\begin{tabular}{|c|c|c|c|}
\hline & \multicolumn{3}{|c|}{ Ln(Total Pay $)_{t+1}$} \\
\hline & (1) & (2) & (3) \\
\hline Attack Proximity & $\begin{array}{c}0.063 * * * \\
(0.000)\end{array}$ & $\begin{array}{c}0.096 * * * \\
(0.000)\end{array}$ & $\begin{array}{c}0.072 * * \\
(0.035)\end{array}$ \\
\hline Pay Gap & $\begin{array}{c}0.022 * * * \\
(0.000)\end{array}$ & & \\
\hline Attack Proximity $\times$ Pay Gap & $\begin{array}{c}0.041 * * \\
(0.038)\end{array}$ & & \\
\hline Excess Turnover & & $\begin{array}{l}0.450^{*} \\
(0.061)\end{array}$ & \\
\hline Attack Proximity $\times$ Excess Turnover & & $\begin{array}{c}-0.620^{* *} \\
(0.029)\end{array}$ & \\
\hline CEO Tenure & & & $\begin{array}{c}0.003^{*} \\
(0.076)\end{array}$ \\
\hline Attack Proximity $\times$ CEO Tenure & & & $\begin{array}{l}0.007^{*} \\
(0.085)\end{array}$ \\
\hline Firm characteristics & & & \\
\hline Firm size & $\begin{array}{c}0.236^{* * *} \\
(0.000)\end{array}$ & $\begin{array}{c}0.241 * * * \\
(0.000)\end{array}$ & $\begin{array}{c}0.244 * * * \\
(0.000)\end{array}$ \\
\hline Volatility & $\begin{array}{c}0.078 \\
(0.757)\end{array}$ & $\begin{array}{c}0.039 \\
(0.895)\end{array}$ & $\begin{array}{c}0.080 \\
(0.771)\end{array}$ \\
\hline $\operatorname{RET}_{[-12,0]}$ & $\begin{array}{c}0.131 * * * \\
(0.000)\end{array}$ & $\begin{array}{c}0.147 * * * \\
(0.000)\end{array}$ & $\begin{array}{c}0.149 * * * \\
(0.000)\end{array}$ \\
\hline$R O A$ & $\begin{array}{c}0.380 * * * \\
(0.000)\end{array}$ & $\begin{array}{c}0.420 * * * \\
(0.000)\end{array}$ & $\begin{array}{c}0.456^{* * *} \\
(0.000)\end{array}$ \\
\hline M/B Ratio & $\begin{array}{c}0.022 * * * \\
(0.000)\end{array}$ & $\begin{array}{c}0.023 * * * \\
(0.000)\end{array}$ & $\begin{array}{c}0.021 * * * \\
(0.000)\end{array}$ \\
\hline Cash/Assets & $\begin{array}{c}-0.002 \\
(0.982)\end{array}$ & $\begin{array}{c}-0.045 \\
(0.556)\end{array}$ & $\begin{array}{l}-0.022 \\
(0.762)\end{array}$ \\
\hline Leverage & $\begin{array}{c}-0.215^{* * *} \\
(0.000)\end{array}$ & $\begin{array}{c}-0.215^{* * *} \\
(0.000)\end{array}$ & $\begin{array}{c}-0.232 * * * \\
(0.000)\end{array}$ \\
\hline Capex/Assets & $\begin{array}{c}0.279 \\
(0.149)\end{array}$ & $\begin{array}{c}0.218 \\
(0.298)\end{array}$ & $\begin{array}{c}0.299 \\
(0.159)\end{array}$ \\
\hline CEO characteristics & & & \\
\hline CEO Age & $\begin{array}{c}-0.001 \\
(0.440)\end{array}$ & $\begin{array}{c}-0.000 \\
(0.694)\end{array}$ & $\begin{array}{l}-0.002 \\
(0.118)\end{array}$ \\
\hline CEO Ownership & $\begin{array}{c}-0.003^{*} \\
(0.087)\end{array}$ & $\begin{array}{c}-0.005^{* *} \\
(0.041)\end{array}$ & $\begin{array}{c}-0.006^{* *} \\
(0.014)\end{array}$ \\
\hline Intercept & Yes & Yes & Yes \\
\hline Year Fixed Effects & Yes & Yes & Yes \\
\hline Firm Fixed Effects & Yes & Yes & Yes \\
\hline Clustered by firm and year & Yes & Yes & Yes \\
\hline Obs & 22,390 & 20,151 & 21,953 \\
\hline Adj. $R^{2}$ & 0.718 & 0.727 & 0.718 \\
\hline
\end{tabular}




\section{Table 10. Effects on other executives and employees}

This table presents coefficients from difference-in-difference (DiD) regressions measuring the effect of attack on the compensation of other executives and rank-and-file employees. All variables are defined in Appendix B and attack proximity is defined as in Table 2. P-values clustered by firm and year are in parentheses. ${ }^{*}, * *$, and $* * *$ represent significance at the $10 \%, 5 \%$, and $1 \%$ levels, respectively.

\begin{tabular}{|c|c|c|c|}
\hline Dependent variable & $\begin{array}{c}\text { (1) } \\
\text { Ln(Other } \\
\text { Executive Pay) })_{t+1}\end{array}$ & $\begin{array}{c}\text { (2) } \\
\text { Ln(Other } \\
\text { Executive Pay) })_{t+1}\end{array}$ & $\begin{array}{c}(3) \\
\text { Ln(Employee } \\
\text { Pay) } \\
t+1\end{array}$ \\
\hline Attack Proximity & $\begin{array}{c}-0.033^{* *} \\
(0.011)\end{array}$ & & $\begin{array}{c}0.008 \\
(0.608)\end{array}$ \\
\hline$\Delta \operatorname{Ln}(\text { Total CEO Pay })_{t+1}$ & & $\begin{array}{c}0.197 * * * \\
(0.000)\end{array}$ & \\
\hline Attack Proximity $\times \Delta$ Ln $(\text { Total CEO Pay })_{t+1}$ & & $\begin{array}{c}-0.037^{*} \\
(0.054)\end{array}$ & \\
\hline \multicolumn{4}{|l|}{ Firm characteristics } \\
\hline Firm size & $\begin{array}{c}0.307 * * * \\
(0.000)\end{array}$ & $\begin{array}{c}0.330 * * * \\
(0.000)\end{array}$ & $\begin{array}{c}0.118 * * * \\
(0.001)\end{array}$ \\
\hline Volatility & $\begin{array}{l}0.416^{*} \\
(0.087)\end{array}$ & $\begin{array}{c}0.427 \\
(0.102)\end{array}$ & $\begin{array}{c}0.342 \\
(0.136)\end{array}$ \\
\hline$R E T_{[-12,0]}$ & $\begin{array}{c}0.130 * * * \\
(0.000)\end{array}$ & $\begin{array}{c}0.116 * * * \\
(0.000)\end{array}$ & $\begin{array}{l}-0.000 \\
(0.961)\end{array}$ \\
\hline$R O A$ & $\begin{array}{c}0.339 * * * \\
(0.000)\end{array}$ & $\begin{array}{c}0.323 * * * \\
(0.000)\end{array}$ & $\begin{array}{l}-0.121 \\
(0.246)\end{array}$ \\
\hline M/B Ratio & $\begin{array}{c}0.031 * * * \\
(0.000)\end{array}$ & $\begin{array}{c}0.035^{* * * *} \\
(0.000)\end{array}$ & $\begin{array}{l}-0.001 \\
(0.718)\end{array}$ \\
\hline Cash/Assets & $\begin{array}{l}-0.060 \\
(0.311)\end{array}$ & $\begin{array}{c}-0.056 \\
(0.383)\end{array}$ & $\begin{array}{l}-0.024 \\
(0.790)\end{array}$ \\
\hline Leverage & $\begin{array}{c}-0.226 * * * \\
(0.000)\end{array}$ & $\begin{array}{c}-0.242 * * * \\
(0.000)\end{array}$ & $\begin{array}{c}0.028 \\
(0.483)\end{array}$ \\
\hline Capex/Assets & $\begin{array}{c}0.559 * * * \\
(0.002)\end{array}$ & $\begin{array}{c}0.625 * * * \\
(0.001)\end{array}$ & $\begin{array}{c}0.059 \\
(0.750)\end{array}$ \\
\hline CEO and other executive characteristics & & & \\
\hline Other Executive Age ${ }_{t}$ & $\begin{array}{c}-0.002 * \\
(0.060)\end{array}$ & $\begin{array}{l}-0.002 \\
(0.123)\end{array}$ & \\
\hline Other Executive Ownership ${ }_{t}$ & $\begin{array}{c}0.001 \\
(0.711)\end{array}$ & $\begin{array}{l}-0.002 \\
(0.588)\end{array}$ & \\
\hline CEO Age & & & $\begin{array}{l}-0.001 \\
(0.266)\end{array}$ \\
\hline CEO Ownership & & & $\begin{array}{c}0.001 \\
(0.574)\end{array}$ \\
\hline Intercept & Yes & Yes & Yes \\
\hline Year Fixed Effects & Yes & Yes & Yes \\
\hline Firm Fixed Effects & Yes & Yes & Yes \\
\hline Clustered by firm and year & Yes & Yes & Yes \\
\hline Obs & 21,822 & 19,624 & 3,510 \\
\hline Adj. $R^{2}$ & 0.783 & 0.807 & 0.924 \\
\hline
\end{tabular}

